\title{
A COMPARISON OF RESULTS OBTAINED WITH TWO SUBSURFACE NON-ISOTHERMAL MULTIPHASE REACTIVE TRANSPORT SIMULATORS, FADES-CORE AND TOUGHREACT
}

\author{
Ricardo Juncosa Riveral, Tianfu X ${ }^{2}$, and Karsten Pruess ${ }^{2}$ \\ ${ }^{1}$ School of Civil Engineering, University of La Coruña, Spain \\ ${ }^{2}$ Earth Sciences Division, Lawrence Berkeley National Laboratory \\ University of California, Berkeley, CA 94720
}

January 2001 


\section{1.- ABSTRACT}

FADES-CORE and TOUGHREACT are codes used to model the non-isothermal multiphase flow with multicomponent reactive transport in porous media. Different flow and reactive transport problems were used to compare the FADES-CORE and TOUGHREACT codes. These problems take into account the different cases of multiphase flow with and without heat transport, conservative transport, and reactive transport. Consistent results were obtained from both codes, which use different numerical methods to solve the differential equations resulting from the various physicochemical processes.

Here we present the results obtained from both codes for various cases. Some results are slightly different with minor discrepancies, which have been remedied, so that both codes would be able to reproduce the same processes using the same parameters. One of the discrepancies found is related to the different calculation for thermal conductivity in heat transport, which affects the calculation of the temperatures, as well as the $\mathrm{pH}$ of the reaction of calcite dissolution problem modeled. Therefore it is possible to affirm that the $\mathrm{pH}$ is highly sensitive to temperature.

Generally speaking, the comparison was concluded to be highly satisfactory, leading to the complete verification of the FADES-CORE code. However, we must keep in mind that, as there are no analytical solutions available with which to verify the codes, the TOUGHREACT code has been thoroughly corroborated, given that the only possible way to prove that the code simulation is correct, is by comparing the results obtained with both codes for the identical proiblems, or to validate the simulation results with actual measured data.

\section{2.- INTRODUCTION}

Code verification is a process by which one checks that the code solves properly the equations it is intended to solve. This process is achieved by comparing the results 
calculated from the code to be verified with the results from the analytical solution of the problem presented or from the results of the other code accepted to be valid.

FADES-CORE is an effective tool for modeling the non-isothermal multiphase flow with multicomponent reactive transport in porous media. The complete verification of the code was not carried out owing to both a lack of analytical solutions and other codes having similar characteristics. FADES-CORE was previously verified for the following cases (Juncosa, 1999):

1) Non-isothermal multiphase flow.

2) Solute transport with a saturated flow and different time integration schemes and different types of elements (1-D and 2-D).

3) Solute transport with radioactive decay (1-D and 2-D).

4) Solute transport with anion exclusion in a saturated flow.

5) Solute transport with adsorption with distribution coefficient in a saturated flow.

6) Solute transport with unsaturated monophase flow.

7) Solute transport with the exclusion of unsaturated monophase flow.

8) Solute transport with adsorption with distribution coefficient in an unsaturated monophase flow.

9) Solute transport with chemical speciation: Redox reaction, exchange, dissolution/precipitation, adsorption, aqueous complexation, and acid/base.

In some cases, FADES-CORE was verified against available analytical solutions. These cases include flow, conservative solute transport, solute transport with anion exclusion, solute transport with adsorption with distribution coefficient, transport with radioactive decay, and reactive transport with dissolution/precipitation. In other cases (when analytical solutions are not available), the code was verified using other widely accepted codes: CORE-LE (Samper et al., 1998) and FADES (Navarro, 1997). Verification of reactive transport with ionic exchange, adsorption and redox reactions was performed using the CORE-LE code, which itself had been verified with the PHREEQM, TRANQL and DYNAMIX (Xu, 1996) codes, respectively. The Doctoral Thesis of $\mathrm{Xu}$ (1996) provides a more detailed review of the verification cases mentioned above. 
The FADES code was tested and its ability to correctly model the liquid flow, alone or linked to deformations was verified. It was later confirmed that it was possible to solve problems in which there was an advective gas flow in addition to the liquid flow and deformations. The verification performed was one-dimensional, two-dimensional and three-dimensional with axial symmetry. Similarly, the conductive and advective flow of energy were verified. The examples used in the verification of FADES were taken from Lloret's Doctoral Thesis (1982). Navarro (1997) describes the examples used to verify the FADES code in his Doctoral Thesis.

The FADES-CORE verification of non-isothermal multiphase flow with reactive transport was not previously carried out. On the other hand, the TOUGHREACT code (Xu and Pruess, 1998), developed at the Lawrence Berkeley National Laboratory (California, USA), is also capable for modeling non-isothermal multiphase flow with reactive transport in porous and fractured media, whose verification had not been completed either. A comparative study using both codes for different cases is a useful way for verification of both codes.

We first presents a brief description of FADES-CORE and TOUGHREACT codes. Then we gives the definitions of the different cases intended to be simulated and comparisons of results obtained with both codes. Finally we draw several conclusions. The following cases were simulated in the present work:

a) Multiphase flow without heat transport.

b) Diffusive solute transport without heat transport.

c) Isothermal diffusive solute transport.

d) Isothermal multiphase flow with conservative solute transport.

e) Isothermal multiphase flow with reactive transport (dissolution/precipitation of calcite).

f) Non-isothermal multiphase flow with conservative solute transport; the calculation of the evaporation is based on the saturation pressure and vapor pressure.

g) Non-isothermal multiphase flow with conservative solute transport. 
h) Multiphase flow with heat transport in a transient state with reactive transport (dissolution/precipitation of calcite).

i) A steady-state non-isothermal multiphase flow with reactive transport (calcite dissolution/precipitation and cation exchange).

\section{3.- DESCRIPTION OF FADES-CORE AND TOUGHREACT CODES}

\section{1.- FADES-CORE}

FADES-CORE (Juncosa, 1999) is a code for modeling non-isothermal multiphase flow and transport problems with chemical reactions, which is obtained using the thermohydro-mechanical code FADES (Navarro, 1997) and the reactive transport code CORELE (Samper et al., 1998). The original FADES was modified, and new subroutines for the calculation of solute transport were added. The geochemical processes of CORE-LE were introduced to the modified FADES, resulting in the FADES-CORE code.

The FADES-CORE code can be applied to saturated flow, unsaturated monophase and multiphase flow (advection and diffusion). The flow is solved in terms of liquid and gas pressures. Heat transport (conduction and advection) is solved in terms of temperature. Both the multiphase flow and the heat transport are solved in association. Once the flow has been solved, the next step is to solve the transport of reactive species using an iterative method. The transport equation is solved in terms of the total concentrations of the primary species. After that, the system of equations for the chemical reactions is solved, which provides the explicit term for the chemical sink/source of the transport equation. The code considers the following geochemical reactions under local equilibrium assumption: homogenous reactions (aqueous complexation, acid/base and redox) and heterogeneous reactions (mineral precipitation/dissolution, adsorption, cation exchange and gas dissolution/exolution), as well as transport with radioactive decay and anion exclusion.

To solve the system of partial differential equations, the finite element method of Bubnov-Galerkin was used for the spatial discretization, while a weighted method was 
employed for the time discretization, using a mass conservative technique (Navarro, 1997). FADES-CORE includes linear and non-linear 1-D elements, triangles and quadrilaterals with different integration points. The code incorporates an automatic algorithm that generates time intervals so that when the process does not show any major changes in the variables, the time interval increases, whereas when there are convergence problems, the time interval decreases. The optimization criterion is related to the residual convergence (balance of mass) and the state variables.

The transport equation is solved once again by taking the chemical term into account. This process is repeated until the convergence criterion, established by the user, is met. The chemical system is solved node-to-node by means of the Newton-Raphson iteration method. Once the primary species concentrations have been obtained, it is necessary to obtain the secondary species concentrations, the amount of dissolved or precipitated mineral, that has been adsorbed and exchanged.

After solving the transport of the reactive species, the variation in the liquid density, caused by the changes in its chemical composition, can be evaluated. If this variation is over $2 \%$, the flow must be solved again after revising the liquid density to be able to go on to the subsequent solution of reactive solute transport. Repetition is not usually necessary, as the solutions are diluted and the influence on the density of the liquid is minimal.

\section{2.- TOUGHREACT}

TOUGHREACT is a non-isothermal reactive chemical transport code $(\mathrm{Xu}$ and Pruess, 1998), which was developed by introducing reactive chemistry into the framework of the existing multi-phase fluid and heat flow code TOUGH2 (Pruess, 1991). The flow and transport in geologic media are based on space discretization by means of integral finite differences (Narasimhan and Witherspoon, 1976). An implicit timeweighting scheme is used for the individual components of the model: flow, transport, and geochemical reaction.

TOUGHREACT has the same ability to solve multiphase flow problems with reactive transport as FADES-CORE. The solution process is similar to the one used by 
FADES-CORE. There are different modules in which the independent variables may vary. After solving the flow, the next step is to solve the reactive transport by using the same sequential iterative scheme. The chemical processes included in TOUGHREACT are similar to those in FADES-CORE. TOUGHREACT considers mineral dissolution/precipitation subject to either kinetics or equilibrium, while FADES-CORE only consider equilibrium. On the other hand, TOUGHREACT is not able to solve anion exclusion. The chemical databases used in the two codes are the same, and both come from the EQ3/6 database (Wolery, 1992).

\section{4.- A COMPARATIVE STUDY OF DIFFERENT CASES}

\section{1.- MULTIPHASE FLOW PROBLEM WITHOUT HEAT TRANSPORT}

A one-dimensional problem was used, representing a $0.13 \mathrm{~m}$ long horizontal column of a clayey medium with an initial liquid saturation of $33.4 \%$ at atmospheric pressure and a temperature of $20{ }^{\circ} \mathrm{C}$. At one end (the coordinate origin), distilled water was injected at a pressure of $1 \mathrm{MPa}$ for 180 days. The other end remained impermeable. A constant temperature of $20{ }^{\circ} \mathrm{C}$ was maintained. Table 1 shows the hydrodynamic parameters used (Villar et al., 1995).

Table 1. List of hydrodynamic parameters for the comparison case 1.

\begin{tabular}{|c|c|}
\hline FLOW PARAMETERS & \\
\hline INTRINSIC PERMEABILITY OF LIQUID & $\mathrm{K}_{\mathrm{il}}=8.3810^{-21} \mathrm{~m}^{2}$ \\
\hline RELATIVE PERMEABILITY OF LIQUID & $\mathrm{k}_{\mathrm{rl}}=\mathrm{S}_{1}^{3}$ \\
\hline INTRINSIC PERMEABILITY OF GAS & $\mathrm{k}_{\mathrm{ig}}=9.10^{-17} \mathrm{~m}^{2}$ \\
\hline RELATIVE PERMEABILITY OF GAS & $\mathrm{k}_{\mathrm{rg}}=\left(1-\mathrm{S}_{1}\right)^{3}$ \\
\hline POROSITY & $\phi=0.41$ \\
\hline SOLID DENSITY & $\rho_{\mathrm{s}}=2.78 \mathrm{~g} / \mathrm{cm}^{3}$ \\
\hline RETENTION CURVE ( $\psi=$ suction, Pa) & $\mathrm{S}_{1}=\frac{1}{\left[1+\left(1.43 \cdot 10^{-7} \cdot \psi\right)^{1 / 0.65}\right]^{0.35}}$ \\
\hline
\end{tabular}


The differences of the two codes in calculating the hydrodynamic parameters such as liquid and gas viscosities, the thermal and mechanical compressibility, are minimal, although the liquid viscosity is calculated in FADES-CORE by means of the following expression:

$$
\mu_{1}=661.2 \cdot 10^{-3}(\mathrm{~T}-229)^{-1.562}
$$

where $\mathrm{T}$ is the Kelvin temperature. The gas viscosity is assumed to be constant in FADES-CORE and equal to

$$
\mu_{\mathrm{g}}=1.7610^{-5} \mathrm{~kg} / \mathrm{m} \mathrm{s}
$$

and the mechanical and thermal compressibility of the water

$$
\begin{aligned}
& \mathrm{c}_{\mathrm{w}}^{\mathrm{p}}=5 \cdot 10^{-7} \mathrm{kPa}^{-1} \\
& \mathrm{c}_{\mathrm{w}}^{\mathrm{t}}=2.1 \cdot 10^{-4}{ }^{\circ} \mathrm{C}^{-1}
\end{aligned}
$$

respectively. The liquid density is calculated in terms of temperature, liquid pressure and thermal and mechanical compressibility by means of the following expression:

$$
\rho_{1}=\rho_{1}^{0} \cdot \exp \left(c_{\mathrm{P}}^{\mathrm{w}} \cdot\left(\mathrm{P}_{1}-\mathrm{P}_{1}^{0}\right)-\mathrm{c}_{\mathrm{T}}^{\mathrm{w}} \cdot\left(\mathrm{T}-\mathrm{T}_{0}\right)\right)
$$

where $\rho_{1}^{0}=998.2 \mathrm{~kg} / \mathrm{m}^{3}$ is the liquid density at the reference temperature of $20^{\circ} \mathrm{C}$ and one atmosphere of pressure. Both the thermal and mechanical compressibility as well as the gas viscosity are not constant in TOUGHREACT and vary with temperature and pressure. However the differences are minor. A total of 100 elements were used in the FADES-CORE simulation, and a total of 200 cells in the TOUGHREACT simulation. Figure 1 shows the distribution of the liquid saturation at different times. The origin of the coordinates coincides with the left end through which hydration occurs. We can see 
that similar results were obtained with both codes for the first comparison case. Slight discrepancies in the results may be attributed to the fact that two different spatial sizes were used. The good agreement enables us to claim that both codes can simulate the same isothermal multiphase flow model and produce the same results.

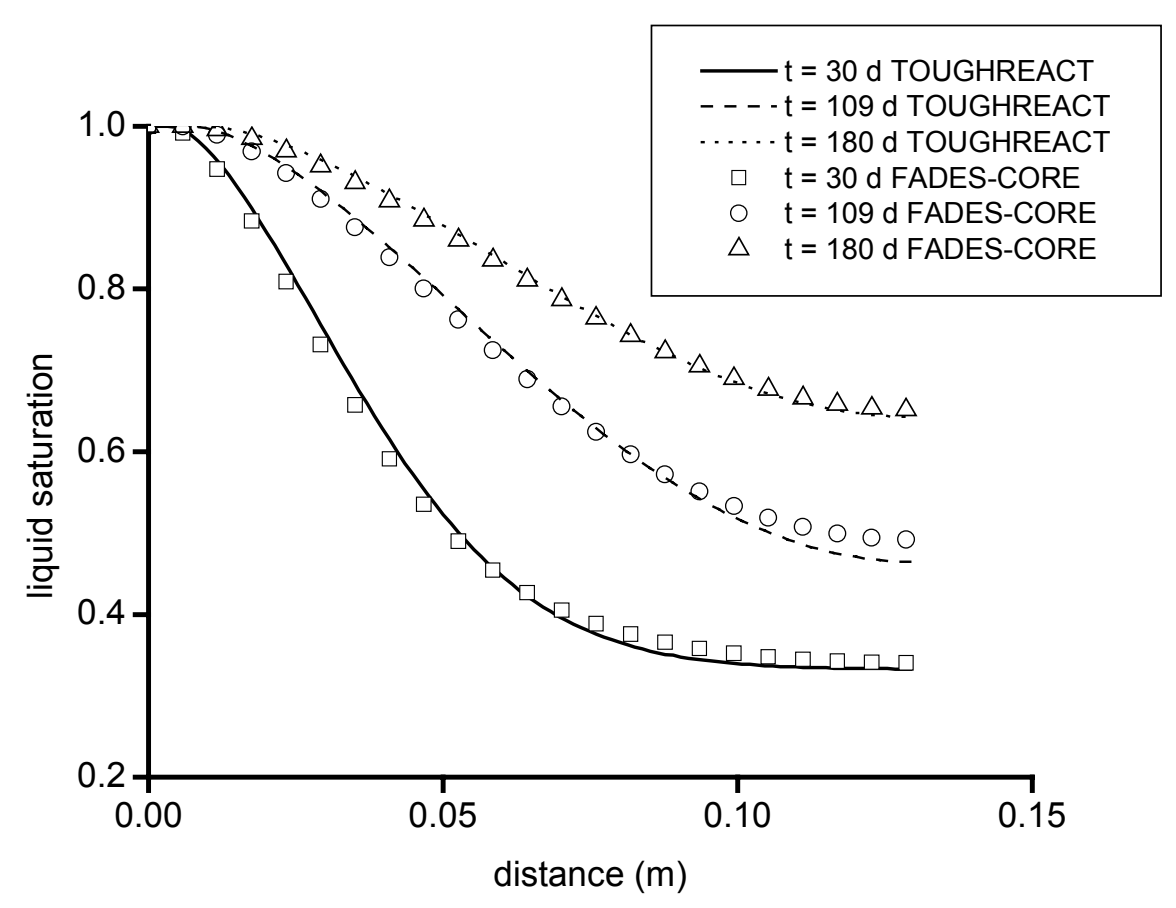

Figure 1. Spatial distribution of liquid saturation at different times obtained with TOUGHREACT and FADES-CORE.

\section{2.- VERIFICATION OF DIFFUSIVE SOLUTE TRANSPORT}

Based on the previous verification case for the unsaturated flow under isothermal conditions, we now verify the conservative transport of a chemical species. We must keep in mind that the TOUGHREACT code differs somewhat from the FADES-CORE code in the presentation of the transport equation. These differences may be summarized as follows: 
a) FADES-CORE allows each primary chemical species to have its own molecular diffusion coefficient, while TOUGHREACT considers all primary chemical species with the same diffusion coefficient.

b) The molecular diffusion coefficient can be calculated in terms of temperature in FADES-CORE.

c) Phenomena of anion exclusion can be modeled with FADES-CORE.

d) FADES-CORE requires the parameter of mechanical dispersion (dispersivity). In TOUGHREACT this parameter is internally calculated by the code depending on the size of the element or cell and the time increment. This helps to avoid numerical dispersion problems since this parameter is basically proportional to the size of the cell.

For these reasons, we developed a simple one-dimensional model for verifying diffusive transport (only diffusion is considered without advection). The model includes only one chemical species with a constant molecular diffusion coefficient, and without anion exclusion. Because advection was not considered, we were able to be sure that the contribution of the mechanical dispersion through dispersivity was zero. A Dirichlet type (fixed concentration) boundary condition for the transport was taken at one end.

The equation governing the transport processes in a saturated medium in an infinite column dimension for an ideal tracer that will not decay or react with the medium is

$$
\phi D \frac{\partial^{2} c}{\partial x^{2}}-q \frac{\partial c}{\partial x}=\phi \frac{\partial c}{\partial t}
$$

where $\phi$ is the porosity, $\mathrm{D}$ is the diffusion coefficient, $\mathrm{q}$ the Darcy velocity, and $\mathrm{c}$ the concentration; with the initial condition

$$
\mathrm{c}(\mathrm{x}, 0)=\mathrm{c}_{\mathrm{i}}
$$

with the Dirichlet type boundary condition, 


$$
(c)_{x=0}= \begin{cases}c_{0} & \text { if } 0<t \leq t_{0} \\ 0 & \text { if } t>t_{0}\end{cases}
$$

At the other end of the column, the condition is

$$
\left.\frac{\partial \mathrm{c}}{\partial \mathrm{x}}\right|_{\mathrm{x}=\infty}=0
$$

The analytical solution is (Mason and Weaver, 1924; Lindstrom et. al., 1967; Gershon and Nir, 1969)

$$
c(x, t)= \begin{cases}c_{i}+\left(c_{0}-c_{i}\right) \cdot A(x, t) & \text { si } 0<t \leq t_{0} \\ c_{i}+\left(c_{0}-c_{i}\right) \cdot A(x, t)-c_{0} \cdot A\left(x, t-t_{0}\right) & \text { si } t>t_{0}\end{cases}
$$

where, defining the real velocity $\mathrm{v}=\mathrm{q} / \phi, \mathrm{A}(\mathrm{x}, \mathrm{t})$ is expressed as

$$
A(x, t)=\frac{1}{2} \operatorname{erfc}\left(\frac{x-v t}{2 \sqrt{D t}}\right)+\frac{1}{2} \exp \left(\frac{v x}{D}\right) \cdot \operatorname{erfc}\left(\frac{x+v t}{2 \sqrt{D t}}\right)
$$

This analytical solution is valid for a constant velocity along the entire column. A simulation was carried out without a flow, assigning a fixed level at both ends of the totally saturated column and equal to the initial level along the entire column. At one end the concentration was fixed at 1 molal (origin of the coordinates). The analytical solution is valid for a semi-infinite medium, which does not occur in reality. Nevertheless it is possible to consider that the front of the concentration is at some distance from the outlet edge, that is; the analytical solution may be accepted as valid as long as the concentrations at the other boundary are negligible.

The parameters used in the numerical simulation are given in Table 2. The numerical simulations were performed using a mesh of 100 elements with FADES- 
CORE and 100 cells with TOUGHREACT. Figure 2 shows that these two codes accurately solve the transport equation after comparing the results obtained using these codes with the analytical solution.

Table 2. List of parameters of the verification case 2 .

\begin{tabular}{|c|c|}
\hline PARÁMETROS & $\mathrm{L}=1 \mathrm{~m}$ \\
\hline LENGTH & $\mathrm{D}_{\mathrm{m}}=5.10^{-4} \mathrm{~m}^{2} / \mathrm{d}$ \\
\hline MOLECULAR DIFFUSION & $\tau=\frac{\theta_{1}^{7 / 3}}{\phi^{2}}$ \\
\hline TORTUOSITY & $\phi=0.3$ \\
\hline $\begin{array}{c}\text { FIXED CONCENTRATION (Dirichlet condition in left } \\
\text { boundary) }\end{array}$ & $\mathrm{c}_{0}=1 \mathrm{molal}$ \\
\hline $\begin{array}{c}\text { POROSITY } \\
\text { RETENTION CURVE }(\psi=\text { suction, Pa) }\end{array}$ & $\mathrm{S}_{1}=\frac{1}{\left[1+\left(1.43 \cdot 10^{-7} \cdot \psi\right)^{1 / 0.65}\right]^{0.35}}$ \\
\hline TIME & $\mathrm{t}_{0}=100 \mathrm{~d}$ \\
\hline
\end{tabular}

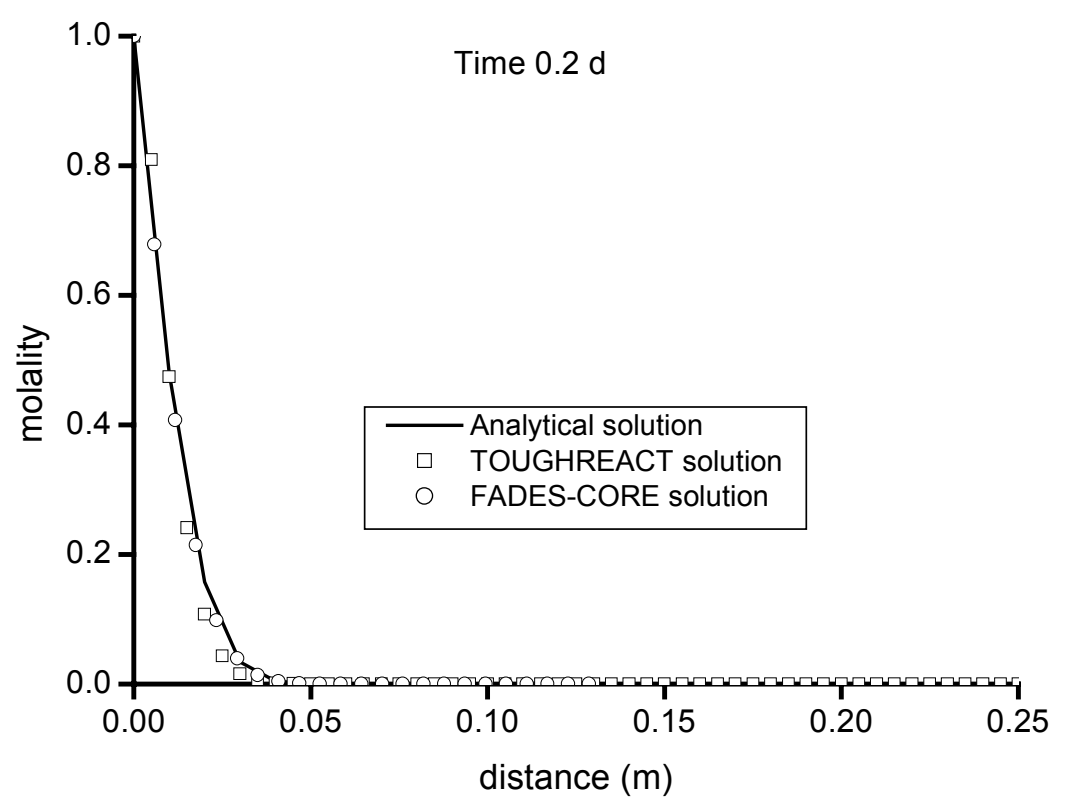

Figure 2. Comparison of analytical solution and concentration at 0.2 days obtained with TOUGHREACT and FADES-CORE. 


\section{3.- ISOTHERMAL DIFFUSIVE SOLUTE TRANSPORT}

This case was used to prove that both codes keep mass balanced. For this purpose, we simulated the diffusion of a solute initially having a point concentration of 1 molal on a node located in an infinite medium. The transport is only diffusive in a saturated medium and there is no advection. The results obtained using the two codes depend on the size of the mesh as the calculation of the terms of the concentration gradient is based on the size of the element. The same sized mesh was therefore used in the simulation with FADES-CORE and TOUGHREACT.

The parameters used in this case are given in Table 3. The numerical simulations were performed using a mesh of 200 elements with FADES-CORE and 200 cells with TOUGHREACT. Figure 3 provides the results obtained at different times using the two codes. The balance of mass was evaluated and found to remain constant.

Table 3. List of parameters used for verification case 3.

\begin{tabular}{|c|c|}
\hline PARAMETERS & \\
\hline LENGTH & $\mathrm{L}=0.26 \mathrm{~m}$ \\
\hline MOLECULAR DIFFUSION & $\mathrm{D}_{\mathrm{m}}=2.10^{-9} \mathrm{~m}^{2} / \mathrm{s}$ \\
\hline TORTUOSITY & $\tau=\frac{\theta_{1}^{7 / 3}}{\phi^{2}}$ \\
\hline POROSITY & $\phi=0.41$ \\
\hline $\begin{array}{c}\text { INITIAL CONCENTRATION (at the middle of the } \\
\text { length) }\end{array}$ & $\mathrm{C}_{0}=1 \mathrm{molal}$ \\
\hline TIME & $\mathrm{t}_{0}=180 \mathrm{~d}$ \\
\hline
\end{tabular}




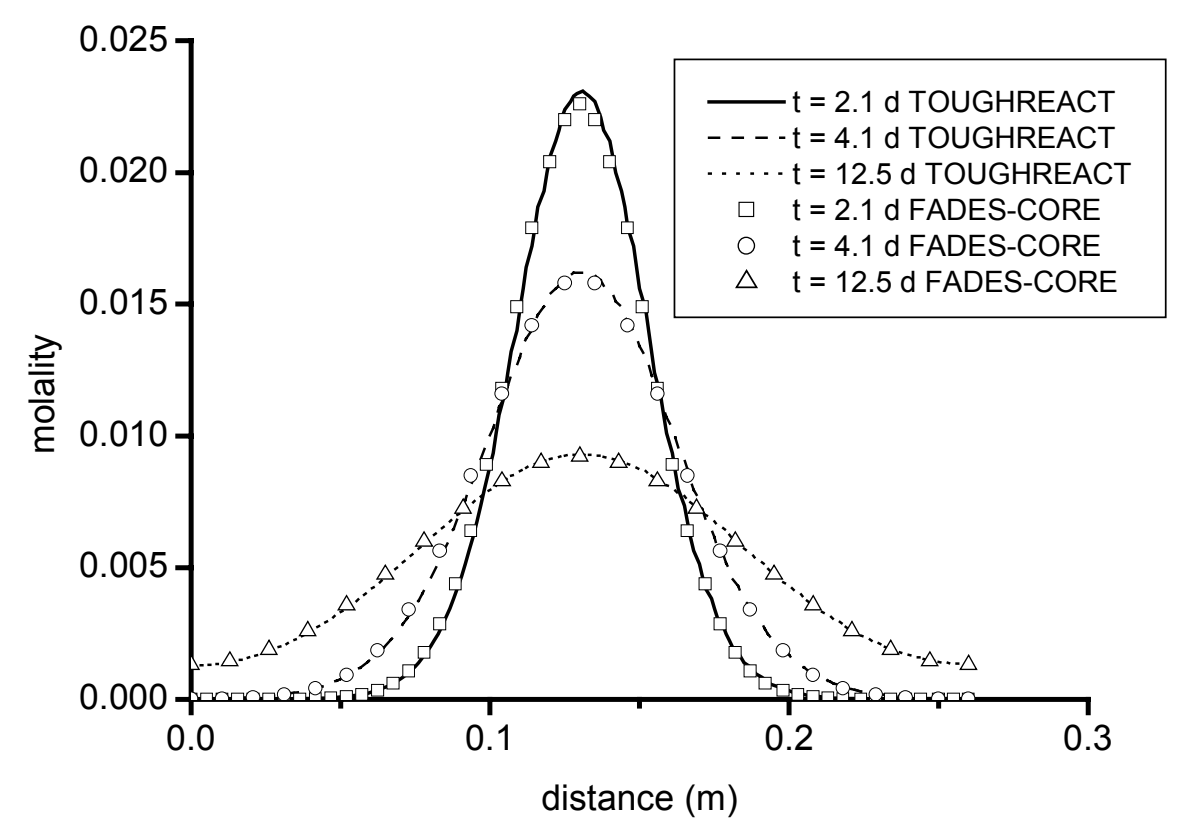

Figure 3. Comparison of concentration distributions at different times obtained with TOUGHREACT and FADES-CORE for the solute diffusion case.

\section{4.- ISOTHERMAL MULTIPHASE FLOW WITH CONSERVATIVE SOLUTE TRANSPORT}

The conservative transport in both codes was verified using the example illustrated in section 4.1. We used the same hydrodynamic parameters used in the first verification case. It was initially assumed that the water in the column has a zero concentration for any chemical species. A Dirichlet type condition, a fixed concentration of one molal, was assigned to the water inlet end. The water flowing through this boundary will transport solute by advection and diffusion to the interior of the column. The transport parameters used are given in Table 4. The molecular diffusion coefficient was assumed to be constant in the simulation. The longitudinal dispersivity is a required parameter in FADES-CORE. This parameter is internally calculated in TOUGHREACT, based mainly on the distance between the geometric centers of two adjacent cells. The 
distance between these centers is constant throughout the entire mesh and equal to $\Delta \mathrm{x}=$ $0.00065 \mathrm{~m}$. TOUGHREACT calculates this dispersivity by means of the following expression:

$$
\alpha_{\mathrm{L}} \approx \frac{\Delta \mathrm{x}}{2}
$$

Thus, the dispersivity value used in FADES-CORE is

$$
\alpha_{\mathrm{L}}=3.2510^{-4} \mathrm{~m}
$$

Comparison of the results obtained at different times using the two codes is given in Figure 4. We can see that the results agree well.

Table 4. List of parameters used for verification case 4.

\begin{tabular}{|c|c|}
\hline PARAMETERS & \\
\hline LONGITUDINAL DISPERSIVITY & $\alpha_{\mathrm{L}}=3.2510^{-4} \mathrm{~m}$ \\
\hline MOLECULAR DIFFUSION & $\mathrm{D}_{\mathrm{m}}=2.10^{-9} \mathrm{~m}^{2} / \mathrm{s}$ \\
\hline TORTUOSITY & $\tau=\frac{\theta_{1}^{7 / 3}}{\phi^{2}}$ \\
\hline POROSITY & $\phi=0.41$ \\
\hline INITIAL CONCENTRATION & $\mathrm{c}_{0}=10^{-20}$ molal \\
\hline BOUNDARY CONCENTRATION & $\mathrm{c}_{\mathrm{c}}=1$. molal \\
\hline TIME & $\mathrm{t}_{0}=180 \mathrm{~d}$ \\
\hline
\end{tabular}




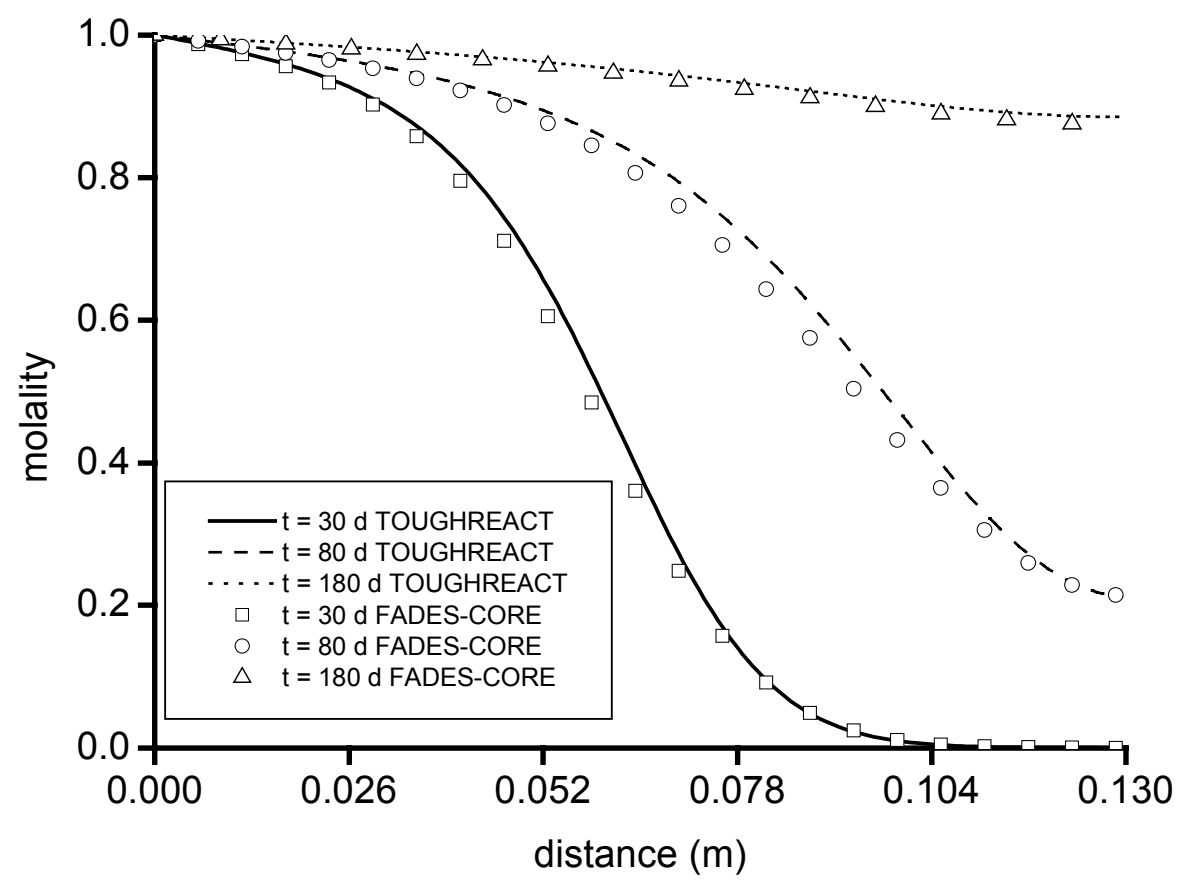

Figure 4. Comparison of concentration distributions at different times obtained with TOUGHREACT and FADES-CORE.

\section{5.-ISOTHERMAL MULTIPHASE FLOW WITH REACTIVE TRANSPORT}

In order to verify the reactive transport, a calcite dissolution problem was modeled with the flow of distilled water through the horizontal column of the above example. We used the same hydrodynamic parameters and mesh size as in the above case. The following primary chemical species were considered: $\mathrm{H}^{+}, \mathrm{Ca}^{2+}$ and $\mathrm{HCO}_{3}^{-}$. The values of the transport parameters are given in Table 5. A same molecular diffusion coefficient was used for the three chemical species. Constant species concentrations (Table 6) were applied at the inflow boundary for transport (Dirichlet type boundary condition). 
Table 5. List of parameters used for verification case 5.

\begin{tabular}{|c|c|}
\hline PARAMETERS & \\
\hline LONGITUDINAL DISPERSIVITY & $\alpha_{\mathrm{L}}=3.2510^{-4} \mathrm{~m}$ \\
\hline MOLECULAR DIFFUSION & $\mathrm{D}_{\mathrm{m}}=2.10^{-9} \mathrm{~m}^{2} / \mathrm{s}$ \\
\hline TORTUOSITY & $\tau=\frac{\theta_{1}^{7 / 3}}{\phi^{2}}$ \\
\hline POROSITY & $\phi=0.41$ \\
\hline TIME & $\mathrm{t}_{0}=180 \mathrm{~d}$ \\
\hline
\end{tabular}

Table 6. Initial and boundary concentrations of primary species.

\begin{tabular}{|c|c|c|}
\hline & $\begin{array}{c}\text { INITIAL MOLAL } \\
\text { CONCENTRATION }\end{array}$ & $\begin{array}{c}\text { BOUNDARY MOLAL } \\
\text { CONCENTRATION }\end{array}$ \\
\hline $\mathrm{H}^{+}$ & $2.3510^{-8}$ & $10^{-7}$ \\
\hline $\mathrm{Ca}^{2+}$ & $3.8110^{-2}$ & $10^{-20}$ \\
\hline $\mathrm{HCO}_{3}^{-}$ & $5.2610^{-4}$ & $10^{-20}$ \\
\hline
\end{tabular}

The initial calcite content was assumed to be $1 \%$ by volume fraction. The dissolution of calcite is controlled by the $\mathrm{pH}$ with the dissolution reaction:

$$
\text { calcite }+\mathrm{H}^{+} \Leftrightarrow \mathrm{Ca}^{2+}+\mathrm{HCO}_{3}^{-}
$$

It is important to keep in mind that the chemical term can be solved explicitly cell by cell or node by node. It means that the verification of the conservative solute transport and chemical reaction equations can be carried out separately. For the chemical processes, it can be verified against a batch geochemical code such as EQ3/6. However, the combined verification of all transport and reaction processes is more realistic and interesting, and can give users some confidence for the code applications.

Figures 5, 6 and 7 provide a comparison of the spatial distributions of the different species at different times, obtained using FADES-CORE and TOUGHREACT. 


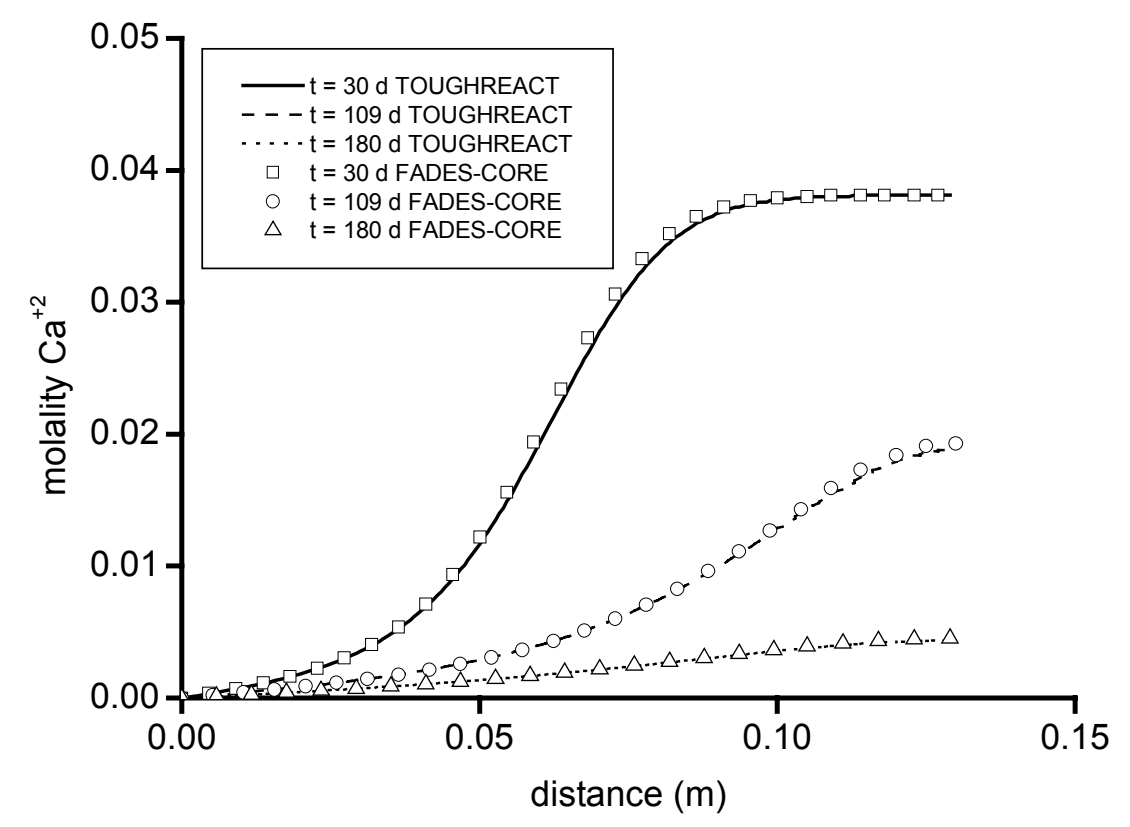

Figure 5. Comparison of $\mathrm{Ca}^{+2}$ concentration distributions at different times obtained with TOUGHREACT and FADES-CORE for calcite dissolution case.

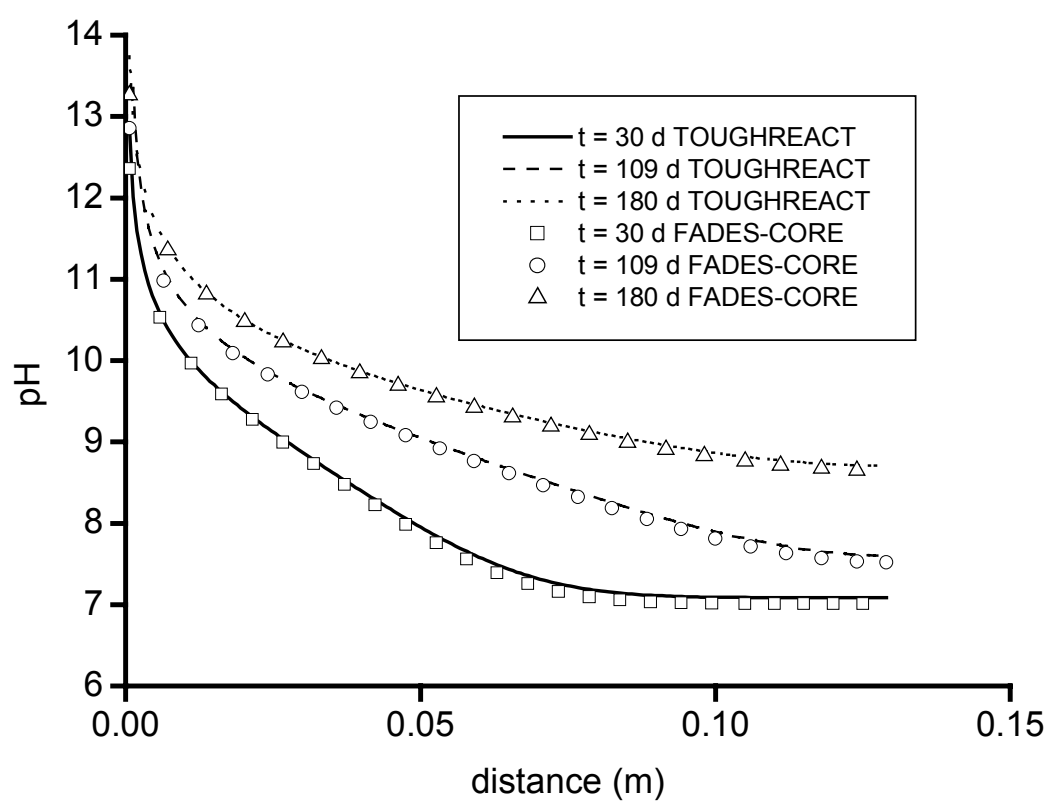

Figure 6. Comparison of $\mathrm{pH}$ distributions at different times obtained with TOUGHREACT and FADES-CORE for calcite dissolution case. 


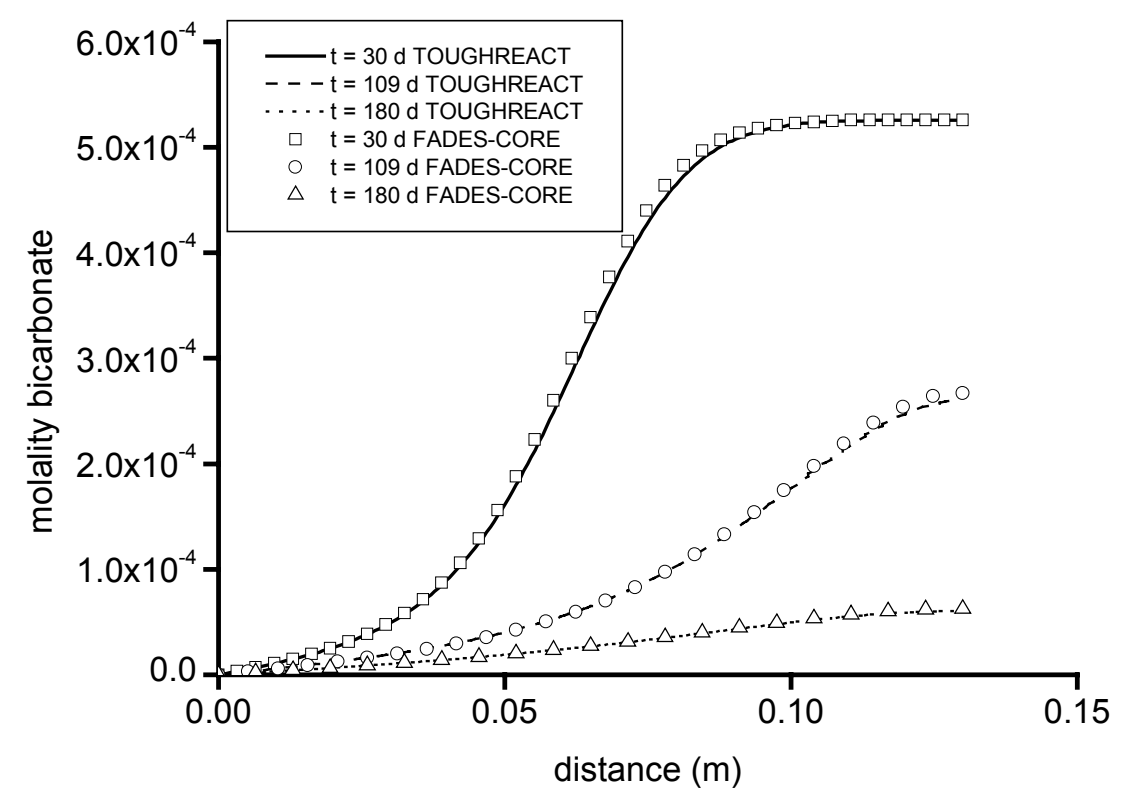

Figure 7. Comparison of bicarbonate concentration distributions at different times obtained with TOUGHREACT and FADES-CORE for calcite dissolution case.

\section{6.- NON-ISOTHERMAL MULTIPHASE FLOW WITH CONSERVATIVE TRANSPORT USING DIFFERENT EVAPORATION MODELS}

This section describes the differences found in the TOUGHREACT code after modeling the cases in which the evaporation rate is calculated from the saturation pressure (module EOS3) and vapor pressure lowering (module EOS4). In EOS4, the calculation of vapor pressure is based on Kelvin's law, which expresses vapor pressure in terms of the function of the saturation pressure, suction and temperature:

$$
P_{v}=P_{v}^{0} \exp \left(P_{w}\left(P_{1}-P_{g}\right) / \rho_{1} R T\right)
$$

where term $\mathrm{P}_{\mathrm{g}}-\mathrm{P}_{1}$ is the suction, $\rho_{1}$ is the liquid density, $\mathrm{P}_{\mathrm{v}}^{0}$ is the vapor pressure when the suction is zero at temperature $\mathrm{T}$ (saturation pressure), $\mathrm{Pm}_{\mathrm{w}}$ is the molecular weight of 
the water, $\mathrm{R}$ is the universal constant of the gases, and $\mathrm{P}_{\mathrm{v}}$ the vapor pressure for an arbitrary state.

The above vapor pressure under zero suction conditions is calculated in FADESCORE by means of the following expression:

$$
\mathrm{P}_{\mathrm{v}}^{0}=\frac{\rho_{\mathrm{v}}^{0} \mathrm{RT}}{\mathrm{Pm}_{\mathrm{w}}}
$$

where $\mathrm{R}$ is the universal gas constant, $\mathrm{T}$ the absolute temperature, $\mathrm{Pm}_{\mathrm{w}}$ the molecular weight of the vapor or water and $\rho_{\mathrm{v}}^{0}$ is the vapor density with null suction, whose value varies depending on the temperature. The vapor density at zero suction has been tabulated.

Under conditions where the suction is not zero, the vapor pressure is consistently lower than the saturation pressure. Therefore, the amount of water vaporized at full saturation pressure is greater than the amount of evaporated water calculated under unsaturated conditions in the porous medium.

The case modeled was heated for 2619 hours at both ends of the $0.13 \mathrm{~m}$ long horizontal column and closed off to the outside. It had an initial water saturation of $50 \%$ at a temperature of $20^{\circ} \mathrm{C}$ and one atmosphere of pressure. We used a 200 cell mesh. The boundary conditions at both ends are of the Dirichlet type $\left(53.3{ }^{\circ} \mathrm{C}\right.$ at the left end and 100 ${ }^{\circ} \mathrm{C}$ at the right end). The hydrodynamic parameters used are given in Table 7 . The thermal parameters are given in Table 8 . The thermal conductivity of the medium is calculated by interpolating between the thermal conductivity of a medium which is totally saturated and totally dry:

$$
\Lambda=\Lambda_{\mathrm{d}}+\sqrt{\mathrm{S}_{1}}\left(\Lambda_{\mathrm{w}}-\Lambda_{\mathrm{d}}\right)
$$

Figure 8 shows the saturation distribution at different times obtained with the two codes. The right boundary being heated to $100{ }^{\circ} \mathrm{C}$ undergoes more evaporation than the left boundary. Based on this figure, we may conclude that when TOUGHREACT is implemented with module EOS3, the evaporation is greater than when the 
TOUGHREACT program is executed with module EOS4 that considers vapor pressure lowering effect.

Table 7. List of hydrodynamic parameters used for case 6.

\begin{tabular}{|c|c|}
\hline FLOW PARAMETERS & \\
\hline INTRINSIC PERMEABILITY OF LIQUID & $\mathrm{K}_{\mathrm{il}}=8.3810^{-21} \mathrm{~m}^{2}$ \\
\hline RELATIVE PERMEABILITY OF LIQUID & $\mathrm{k}_{\mathrm{rl}}=\mathrm{S}_{1}^{3}$ \\
\hline INTRINSIC PERMEABILITY OF GAS & $\mathrm{k}_{\mathrm{ig}}=9.10^{-17} \mathrm{~m}^{2}$ \\
\hline RELATIVE PERMEABILITY OF GAS & $\mathrm{k}_{\mathrm{rg}}=\left(1-\mathrm{S}_{1}\right)^{3}$ \\
\hline POROSITY & $\phi=0.41$ \\
\hline SOLID DENSITY & $\rho_{\mathrm{s}}=2.78 \mathrm{~g} / \mathrm{cm}^{3}$ \\
\hline RETENTION CURVE $(\psi=$ suction, Pa) & $\left.\mathrm{S}_{1}=\frac{1}{1+\left(1.43 \cdot 10^{-7} \cdot \psi\right)^{1 / 0.75}}\right]^{0.25}$ \\
\hline
\end{tabular}

Table 8. List of thermal parameters used for case 6.

\begin{tabular}{|c|c|}
\hline THERMAL PARAMETERS & \\
\hline SPECIFIC HEAT OF CLAY & $\mathrm{C}_{\mathrm{b}}=835.5 \mathrm{~J} / \mathrm{kg}{ }^{\circ} \mathrm{C}$ \\
\hline $\begin{array}{c}\text { THERMAL CONDUCTIVITY OF MEDIUM WITH } \\
\text { SATURATED CONDICTION }\end{array}$ & $\Lambda_{\mathrm{w}}=0.9717 \mathrm{~J} / \mathrm{s} \mathrm{m}{ }^{\circ} \mathrm{C}$ \\
\hline THERMAL CONDUCTIVITY OF DRY MEDIUM & $\Lambda_{\mathrm{d}}=0.7535 \mathrm{~J} / \mathrm{s} \mathrm{m}{ }^{\circ} \mathrm{C}$ \\
\hline VAPOR TORTUOSITY & $\tau_{\mathrm{v}}=0.5$ \\
\hline
\end{tabular}




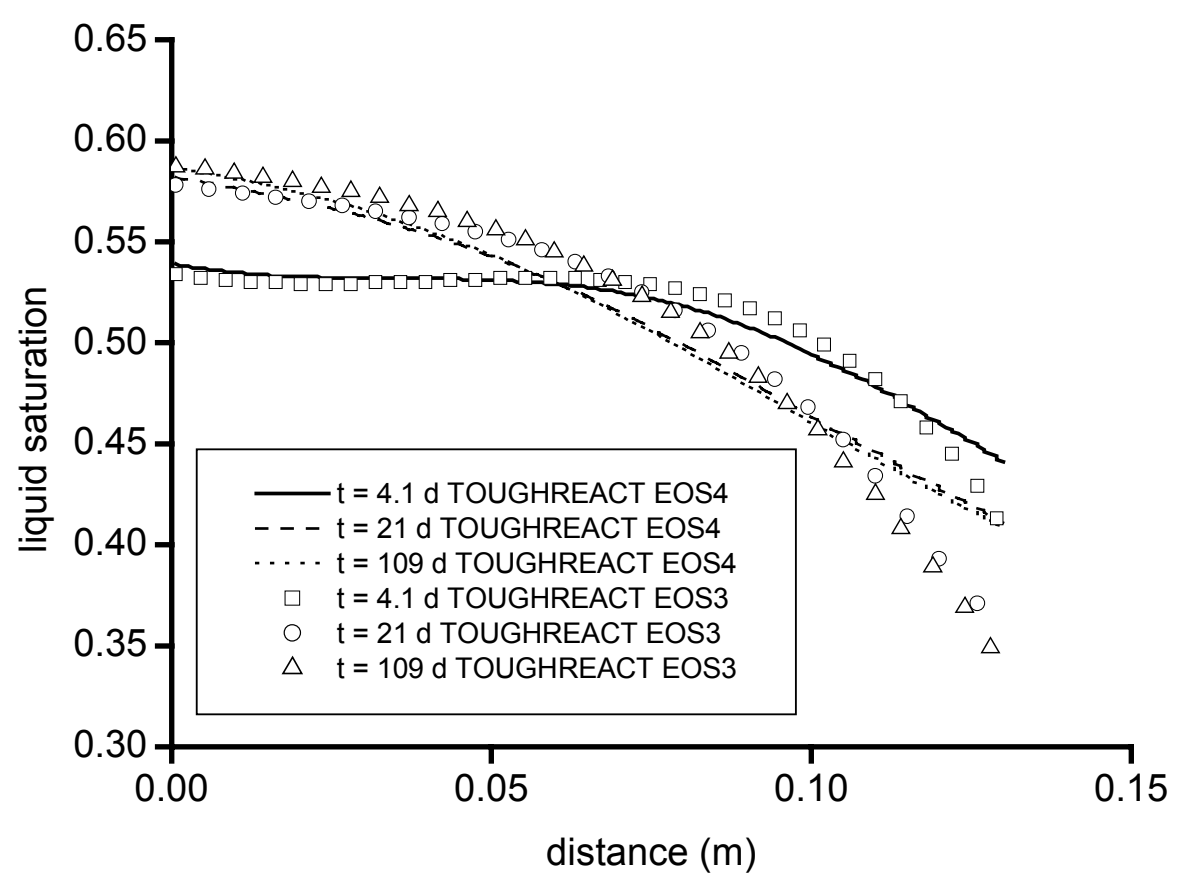

Figure 8. Comparison of liquid saturation distributions at different times using EOS3 and EOS4 modules with TOUGHREACT.

Obviously, the greater evaporation at the boundary will have an effect on the conservative transport. In order to determine the effect of evaporation on the transport of a solute, we simulated the transport of a conservative solute that has an initial concentration of 1 molal along the entire column. The greatest evaporation took place at the right end. The transport parameters used are listed in Table 9. The horizontal column remained closed and heating began at $53.3{ }^{\circ} \mathrm{C}$ (left end) and $100{ }^{\circ} \mathrm{C}$ (right end) respectively. Figure 9 shows concentration distribution obtained with TOUGHREACT. We can see that the concentrations at the right boundary obtained using EOS3 module are much greater than those using EOS4 that considers vapor pressure lowering effect. The latter model is more realistic, given that in the former, evaporation has been calculated under conditions of total saturation, which is not true. 
Table 9. List of solute transport parameters used.

\begin{tabular}{|c|c|}
\hline PARAMETERS & \\
\hline MOLECULAR DIFFUSION & $\mathrm{D}_{\mathrm{m}}=2.10^{-9} \mathrm{~m}^{2} / \mathrm{s}$ \\
\hline TORTUOSITY & $\tau=\frac{\theta_{1}^{7 / 3}}{\phi^{2}}$ \\
\hline
\end{tabular}

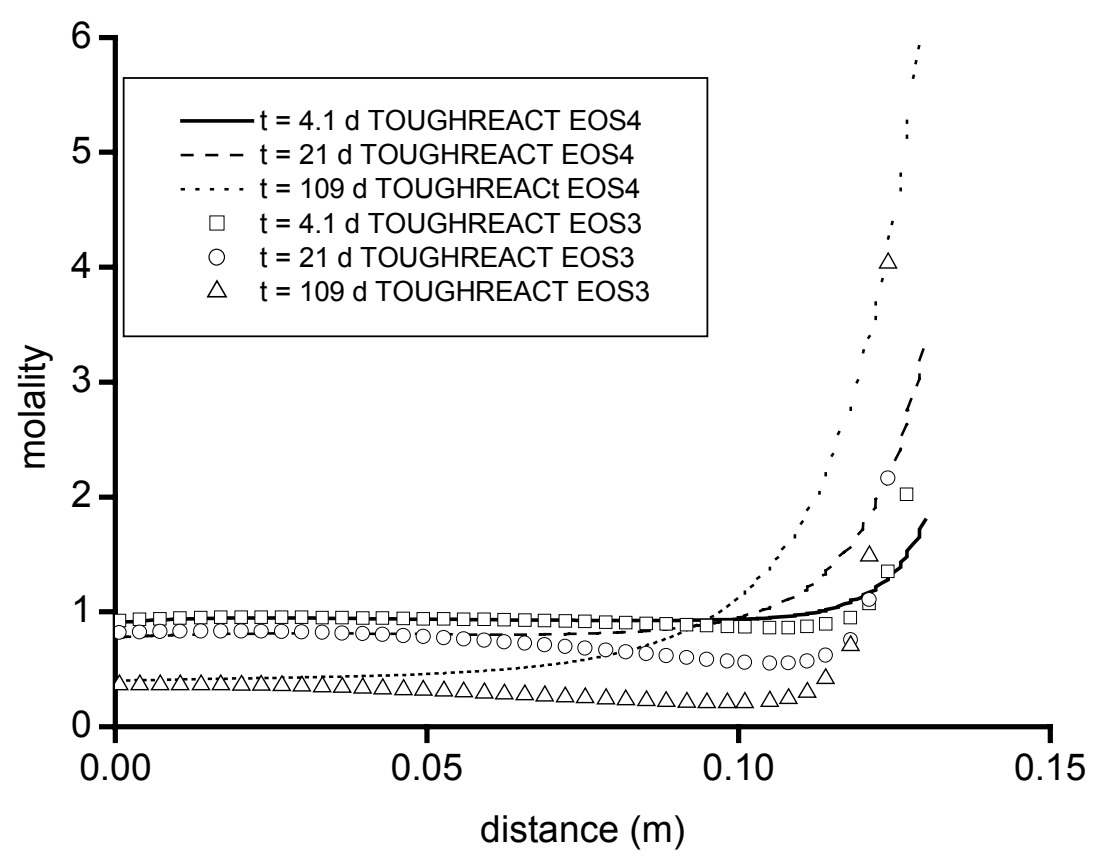

Figure 9. Comparison of molality distributions at different times using EOS3 and EOS4 modules with TOUGHREACT. 


\section{7.- NON-ISOTHERMAL MULTIPHASE FLOW WITH CONSERVATIVE SOLUTE TRANSPORT.}

For the purpose of verification of the conservative transport under non-isothermal multiphase flow conditions, we still used the previous case (Section 4.6). For this reason, TOUGHREACT module EOS4 was chosen, which considers vapor pressure lowering effect. TOUGHREAT simulation uses a mesh of 200 cells, FADES-CORE uses 200 sized elements.

The temperature of the column was initially $53.3{ }^{\circ} \mathrm{C}$ with $50 \%$ saturation at one atmosphere of pressure. The column was completely leak-proof. The hydrodynamic and thermal parameters used in the example are given in Tables 7 and 8. In this case, the heat transport has very little effect on the multiphase flow and conservative solute transport, since the steady conditions are reached after 4 hours with TOUGHREACT, and after 10 hours with FADES-CORE. Figure 10 shows liquid saturation obtained with the two codes. Saturations obtained with the two codes agree reasonably well.

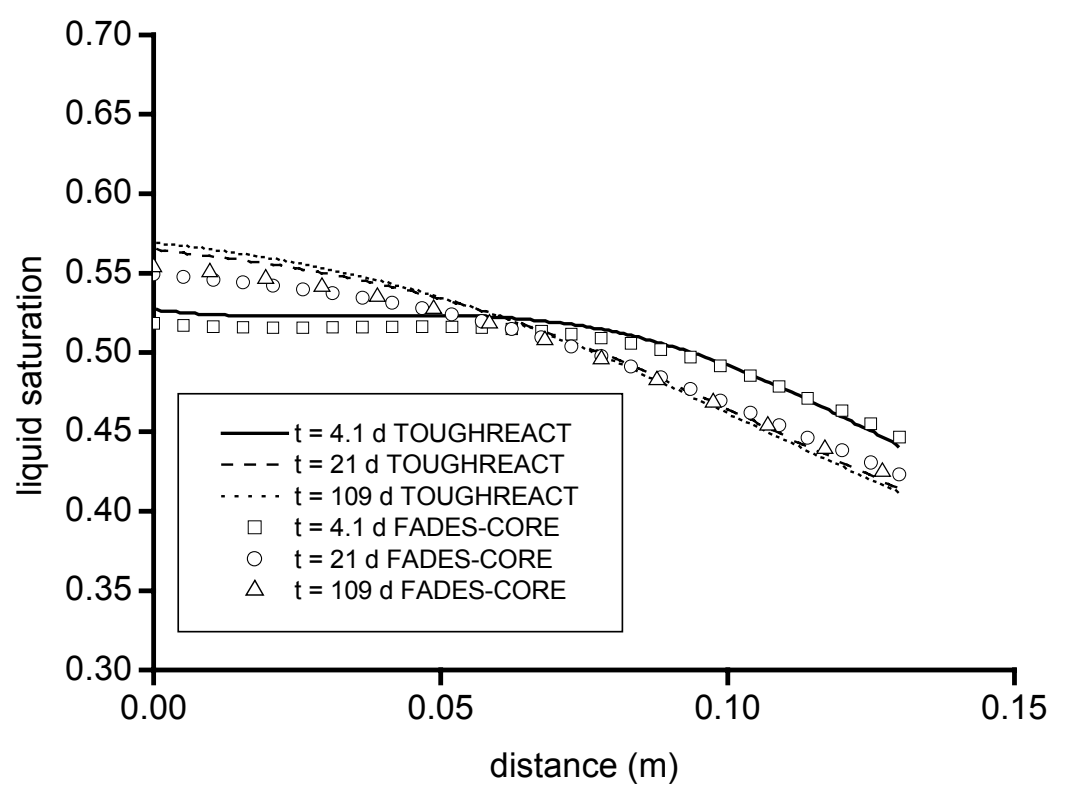

Figure 10. Comparison of liquid saturation distribution at different times obtained with TOUGHREACT and FADES-CORE. 
Furthermore, we verified the conservative transport under this non-isothermal multiphase flow condition. We used an initial concentration of 1 molal along the entire column. The parameters used for solute transport are also listed in Table 9. Concentrations simulated by both codes are identical (Figure 11). The evaporation at the right end increases the concentration considerably.

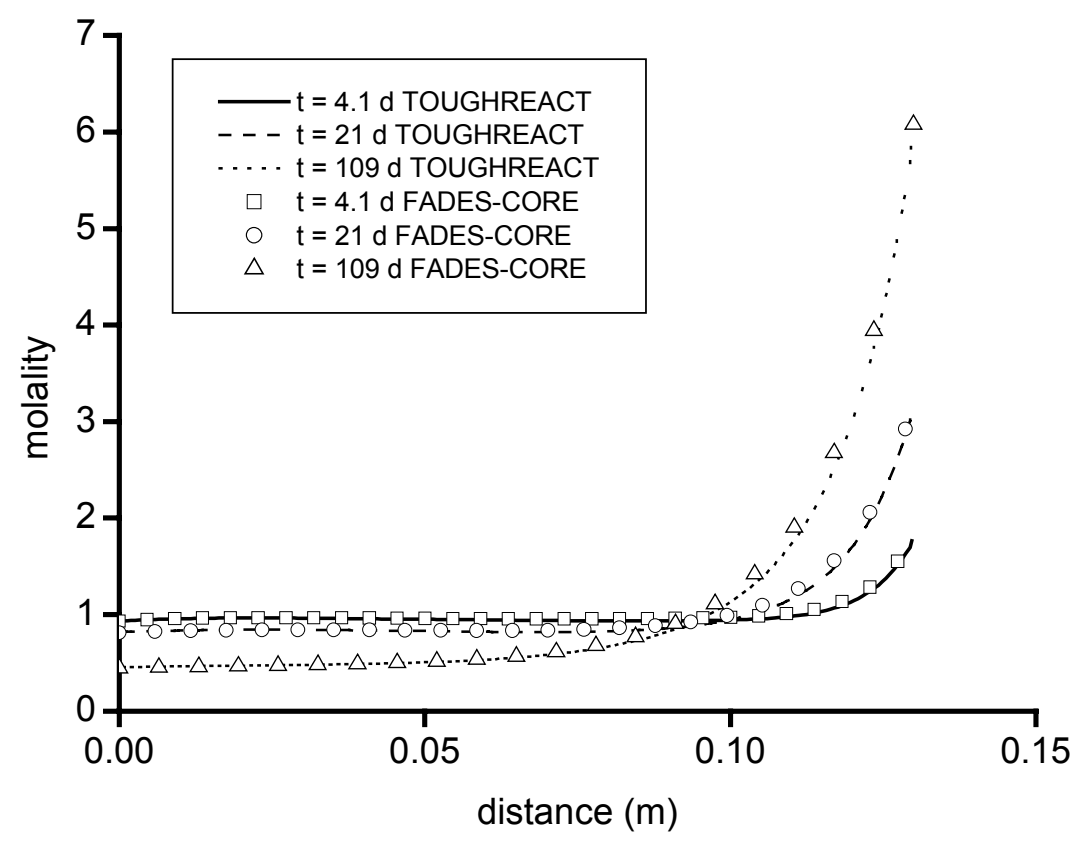

Figure 11. Comparison of molality distributions at different times obtained with TOUGHREACT and FADES-CORE.

\section{8.- NON-ISOTHERMAL MULTIPHASE FLOW WITH REACTIVE $\begin{array}{llllll}\text { TRANSPORT UNDER A TRANSIENT HEAT TRANSPORT } & \text { T }\end{array}$ CONDITION.}

Prior to verify the non-isothermal multiphase flow with reactive transport, we must make sure that the heat transport simulated with both codes is the same and that the calculation of the evaporation rate is also the same. With regard to the latter, a study has 
already been carried out comparing the calculation of evaporation rates with different models in TOUGHREACT. With FADES-CORE it is possible to calculate the evaporation rate by separating the equation for the balance of water mass into a balance of water mass which comprises the liquid phase and a balance of vapor mass. The results obtained from the calculation of the evaporation rate are the same as those resulting from the calculation of this rate based on water pressure, which will be illustrated in the following section.

It must be noted that the temperature has a considerable effect on the equilibrium constant of the reactions, and particularly for great differences in the order of magnitude of primary species concentrations. Therefore, it is essential for the same model to be applied to heat transport in both codes.

Both codes simulate conductive and advective heat transport, the only difference being the calculation of the thermal conductivity of the medium. In the previous case, the results obtained with the two codes are identical because the steady-state of the heat transport was reached rapidly. It should be pointed out that temperature is of considerable importance for calculating the equilibrium constants of the reactions.

The verification of conservative solute transport would be sufficient as the geochemistry is explicitly solved in both codes. Nonetheless, we have developed a more complete model where temperature has had a crucial effect on the calculation of the reactions.

We simulated the heating of the right boundary of the column to $100^{\circ} \mathrm{C}$ from 53.3 ${ }^{\circ} \mathrm{C}$. Hydration was carried out by allowing water to enter at the left boundary at a pressure of 10 bars. The medium has an initial saturation of $50 \%$ at one atmosphere of pressure. The heating took 2619 hours. The meshes used are the same as the previous case. The hydrodynamic parameters used are also listed in Table 7.

The thermal conductivity model applied in TOUGHREACT can be expressed as:

$$
\Lambda=\Lambda_{\mathrm{d}}+\sqrt{\mathrm{S}_{1}}\left(\Lambda_{\mathrm{w}}-\Lambda_{\mathrm{d}}\right)
$$

where $\Lambda_{\mathrm{w}}$ is the thermal conductivity of the medium under saturated conditions and $\Lambda_{\mathrm{d}}$ is the thermal conductivity of the medium under dry conditions. The thermal parameters 
used in TOUGHREACT are shown in Table 8 above. While, the thermal conductivity model used by FADES-CORE is the result of a weighted mean expressed as follows:

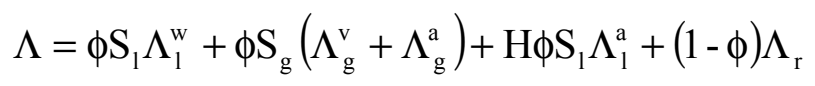

where $S_{g}$ and $S_{1}$ are the degrees of gas and liquid saturation, respectively, $H$ is the volumetric expression of Henry's law (the ratio between the volume of dissolved air and the total liquid volume), $\Lambda_{1}^{\mathrm{w}}, \Lambda_{\mathrm{g}}^{\mathrm{v}}, \Lambda_{1}^{\mathrm{a}}, \Lambda_{\mathrm{g}}^{\mathrm{a}}$ (with $\Lambda_{\mathrm{a}}=\Lambda_{1}^{\mathrm{a}}=\Lambda_{\mathrm{g}}^{\mathrm{a}}$ ) and $\Lambda_{\mathrm{r}}$ is the thermal conductivity of water, vapor, air and the solid matrix, respectively. The thermal parameters used in the FADES-CORE simulation are given in Table 10. The thermal conductivity expression used by TOUGHREACT has a higher value than that used by FADES-CORE. Higher temperatures were obtained with TOUGHREACT than with FADES-CORE. Although these differences do not significantly affect the flow, they do influence reactive transport. A problem for the dissolution of calcite on the horizontal column was simulated using both codes. Distilled water was introduced at the left boundary. The transport parameters and initial concentrations applied are given in Tables 11 and 12.

Table 10. List of thermal parameters used in FADES-CORE simulation.

\begin{tabular}{|c|c|}
\hline THERMAL PARAMETERS & \\
\hline SPECIFIC HEAT OF WATER & $\mathrm{c}_{\mathrm{w}}=4202 \mathrm{~J} / \mathrm{kg}^{\circ} \mathrm{C}$ \\
\hline SPECIFIC HEAT OF AIR & $\mathrm{c}_{\mathrm{a}}=1000 \mathrm{~J} / \mathrm{kg}{ }^{\circ} \mathrm{C}$ \\
\hline SPECIFIC HEAT OF VAPOR & $\mathrm{c}_{\mathrm{v}}=1620 \mathrm{~J} / \mathrm{kg}{ }^{\circ} \mathrm{C}$ \\
\hline SPECIFIC HEAT OF CLAY & $\mathrm{c}_{\mathrm{b}}=835.5 \mathrm{~J} / \mathrm{kg}{ }^{\circ} \mathrm{C}$ \\
\hline VAPORATION ENTHALPY & $2.45410^{6} \mathrm{~J} / \mathrm{kg}$ \\
\hline THERMAL CONDUCTIVITY OF WATER & $\Lambda_{\mathrm{w}}=0.6 \mathrm{~J} / \mathrm{s} \mathrm{m}^{\circ} \mathrm{C}$ \\
\hline THERMAL CONDUCTIVITY OF AIR & $\Lambda_{\mathrm{a}}=2.610^{-2} \mathrm{~J} / \mathrm{s} \mathrm{m}^{\circ} \mathrm{C}$ \\
\hline THERMAL CONDUCTIVITY OF VAPOR & $\Lambda_{\mathrm{v}}=4.210^{-2} \mathrm{~J} / \mathrm{s} \mathrm{m}^{\circ} \mathrm{C}$ \\
\hline THERMAL CONDUCTIVITY OF CLAY & $\Lambda_{\mathrm{b}}=1.23 \mathrm{~J} / \mathrm{s} \mathrm{m}{ }^{\circ} \mathrm{C}$ \\
\hline
\end{tabular}


Table 11. List of solute transport parameter.

\begin{tabular}{|c|c|}
\hline PARAMETERS & \\
\hline LONGITUDINAL DISPERSIVITY & $\alpha_{\mathrm{L}}=3.2510^{-4} \mathrm{~m}$ \\
\hline MOLECULAR DIFFUSION & $\mathrm{D}_{\mathrm{m}}=2.10^{-9} \mathrm{~m}^{2} / \mathrm{s}$ \\
\hline TORTUOSITY & $\tau=\frac{\theta_{1}^{7 / 3}}{\phi^{2}}$ \\
\hline
\end{tabular}

Table 12. List of initial and boundary concentrations of primary species.

\begin{tabular}{|c|c|c|}
\hline & $\begin{array}{c}\text { INITIAL MOLAL } \\
\text { CONCENTRATION }\end{array}$ & $\begin{array}{c}\text { BOUNDARY MOLAL } \\
\text { CONCENTRATION }\end{array}$ \\
\hline $\mathrm{H}^{+}$ & $2.8110^{-8}$ & $10^{-7}$ \\
\hline $\mathrm{Ca}^{2+}$ & $3.8110^{-2}$ & $10^{-20}$ \\
\hline $\mathrm{HCO}_{3}^{-}$ & $5.2610^{-4}$ & $10^{-20}$ \\
\hline
\end{tabular}

The initial calcite content was assumed to be $1 \%$ by volume fraction. The dissolution of calcite is controlled by the $\mathrm{pH}$. The longitudinal dispersivity value is a required parameter in FADES-CORE. Its value was estimated in terms of the size of the mesh used in TOUGHREACT.

Figures 12, 13, 14 and 15 show the distributions of liquid saturation, species concentrations, and $\mathrm{pH}$, respectively. From these figures, we can see that liquid saturation and concentrations simulated using TOUGHREACT and FADES-CORE are consistent. However, pH (Figure 15) and temperature distribution (Figure 16) do not agree well, particularly in the area near the right boundary with the Dirichlet condition of $100{ }^{\circ} \mathrm{C}$. This difference is due to the different thermal conductivities used in each code. 


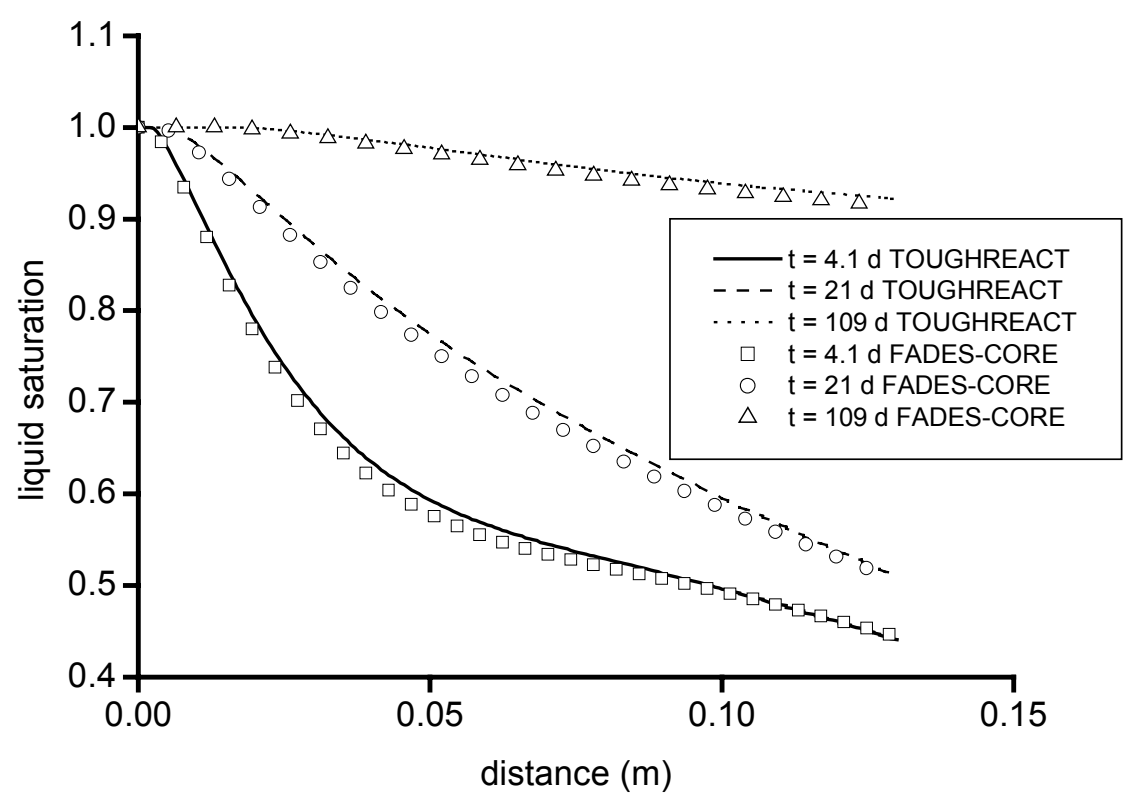

Figure 12. Comparison of liquid saturation obtained at different times with TOUGHREACT and FADES-CORE.

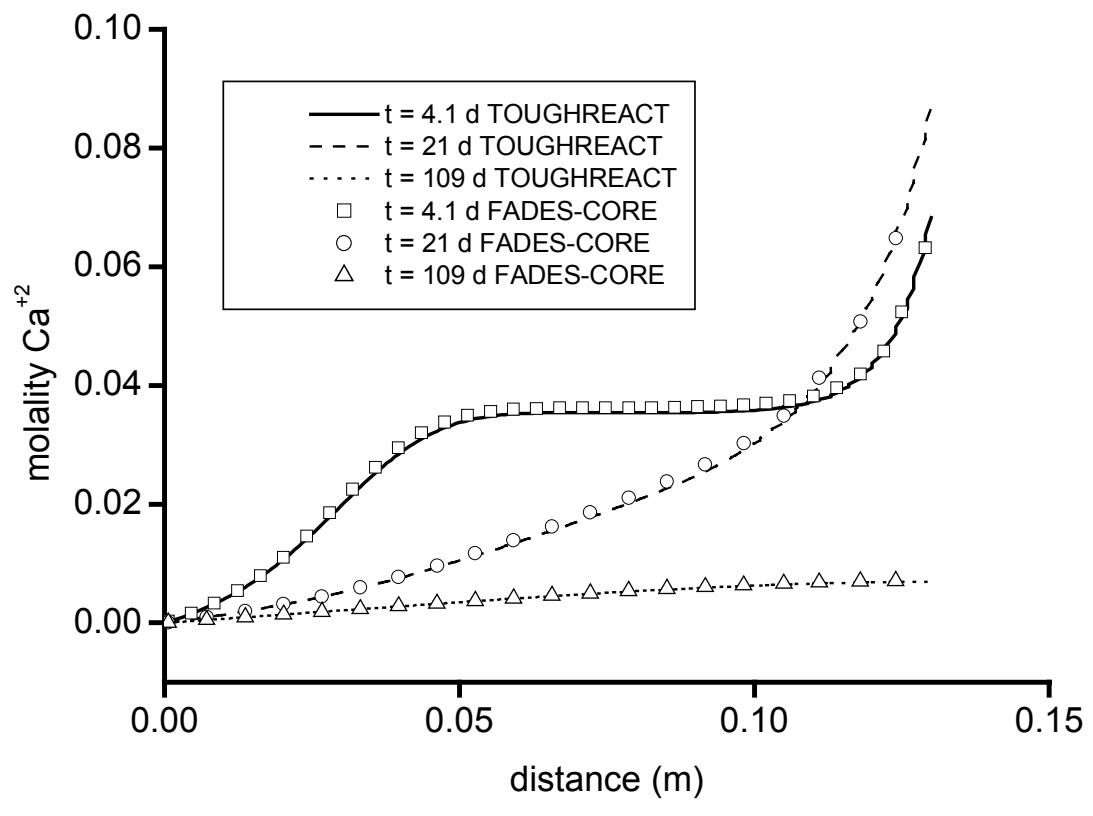

Figure 13. Comparison of $\mathrm{Ca}^{+2}$ concentration at different times obtained with TOUGHREACT and FADES-CORE. 


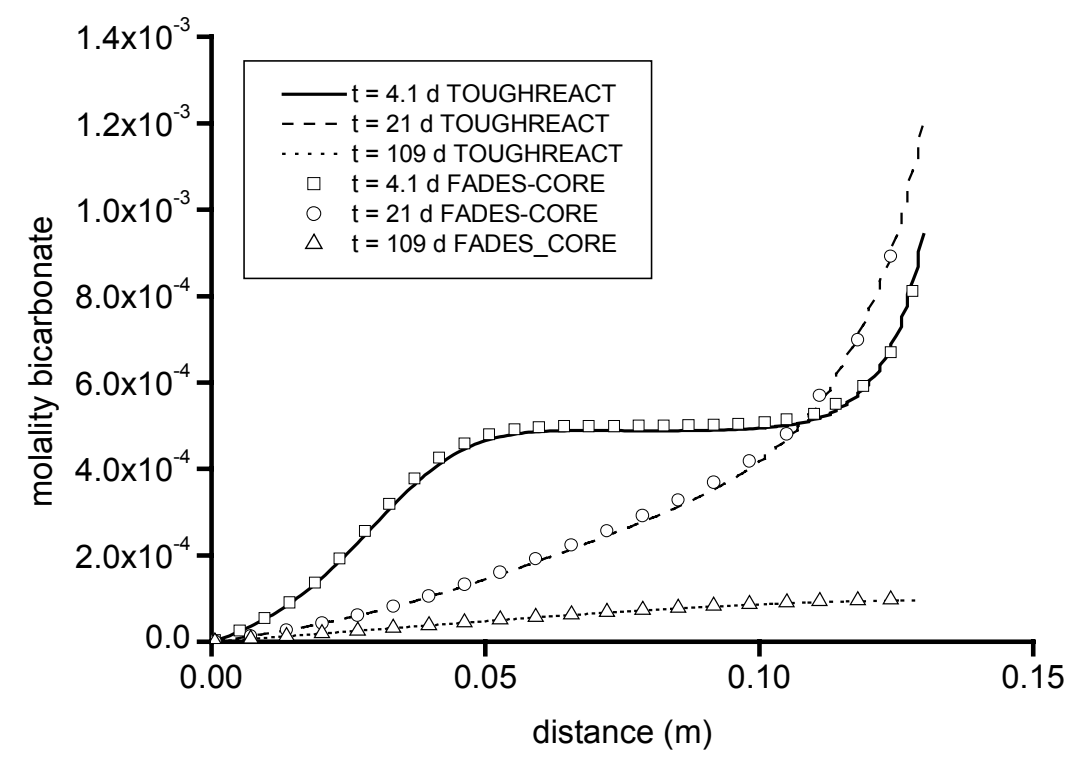

Figure 14. Comparison of bicarbonate concentration at different times obtained with TOUGHREACT and FADES-CORE.

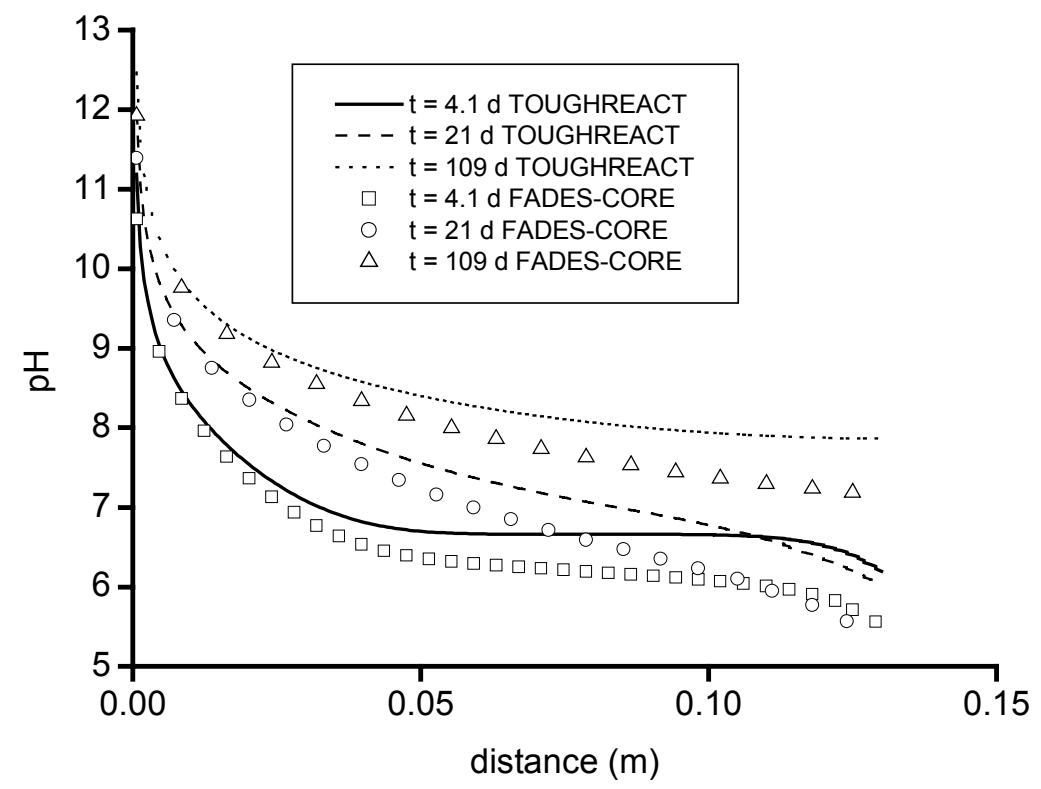

Figure 15. Comparison of $\mathrm{pH}$ concentration distribution at different times obtained with TOUGHREACT and FADES-CORE. 
It is worthy to note that $\mathrm{H}^{+}$concentrations are three orders of magnitude lower than those of $\mathrm{Ca}^{2+}$ and $\mathrm{HCO}_{3}^{-}$. Slight differences in the results of $\mathrm{Ca}^{2+}$ and $\mathrm{HCO}_{3}^{-}$ concentrations may have significant effects on $\mathrm{pH}$. From Figure 16, we can see the difference in temperatures occurring in the area close to the right heat source. It is obvious that the temperature differences of around $8{ }^{\circ} \mathrm{C}$ during the initial times $(1$ minute) are enough to cause the chemical equilibrium constant to fluctuate so that different $\mathrm{pH}$ values were obtained in these times. This variation in the results means that we must start from different $\mathrm{pH}$ values and that this variation must be used up to the final time. Later, the temperature distribution obtained with the two codes will converge, resulting in the same values.

In order to mitigate this effect, in the following example we present a model for the same case using a steady-state heat transport.

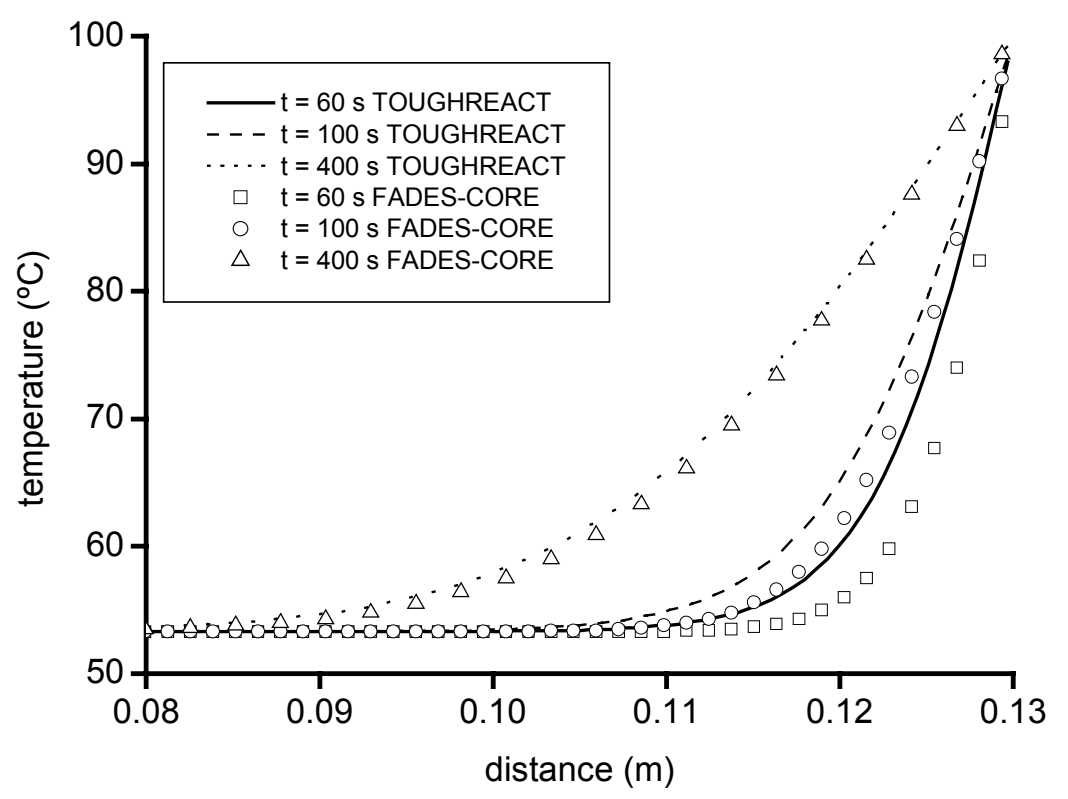

Figure 16. Comparison of temperature distributions at different times obtained with TOUGHREACT and FADES-CORE. 


\section{9.- NON-ISOTHERMAL MULTIPHASE FLOW WITH REACTIVE TRANSPORT UNDER A STEADY-STATE HEAT TRANSPORT CONDITION.}

As mentioned above, the two codes calculate the thermal conductivity of the medium in different ways, which results in different results near the heat source. In order to eliminate this discrepancy, a model was developed based on the previous case but with a steady-state heat transport. The temperature distribution used in this case was taken from the steady-state heat transport in the previous case. Cation exchange was also added for the purpose of developing a more complex case.

Tables 13 and 14 give the initial and boundary concentrations. The following cation exchange reaction was modeled:

$$
\mathrm{Na}^{+}+0.5 \mathrm{Ca}-\mathrm{X}_{2} \Leftrightarrow 0.5 \mathrm{Ca}^{2+}+\mathrm{Na}-\mathrm{X}
$$

The total CEC (cation exchange capacity) is $58 \mathrm{meq} / 100 \mathrm{~g}$. The results obtained using the two codes are presented in Figures 17, 18, 19, 20 and 21. Based on these figures, we may conclude that both codes are able to accurately reproduce the same results when they simulate identical conceptual models.

Table 13. List of initial and boundary concentrations of aqueous primary species.

\begin{tabular}{|c|c|c|}
\hline & $\begin{array}{c}\text { INITIAL MOLAL } \\
\text { CONCENTRATION }\end{array}$ & $\begin{array}{c}\text { BOUNDARY MOLAL } \\
\text { CONCENTRATION }\end{array}$ \\
\hline $\mathrm{H}^{+}$ & $2.8110^{-8}$ & $10^{-7}$ \\
\hline $\mathrm{Ca}^{2+}$ & $3.8110^{-2}$ & $10^{-20}$ \\
\hline $\mathrm{Na}^{+}$ & $3.1710^{-1}$ & $10^{-20}$ \\
\hline $\mathrm{HCO}_{3}^{-}$ & $5.2610^{-4}$ & $10^{-20}$ \\
\hline
\end{tabular}


Table 14. List of initial exchanged cation concentrations.

\begin{tabular}{|c|c|}
\hline EXCHANGE CATIONS & $(\mathrm{meq} / 100 \mathrm{~g})$ \\
\hline $\mathrm{Na}^{+}$ & 24. \\
\hline $\mathrm{Ca}^{2+}$ & 34. \\
\hline
\end{tabular}

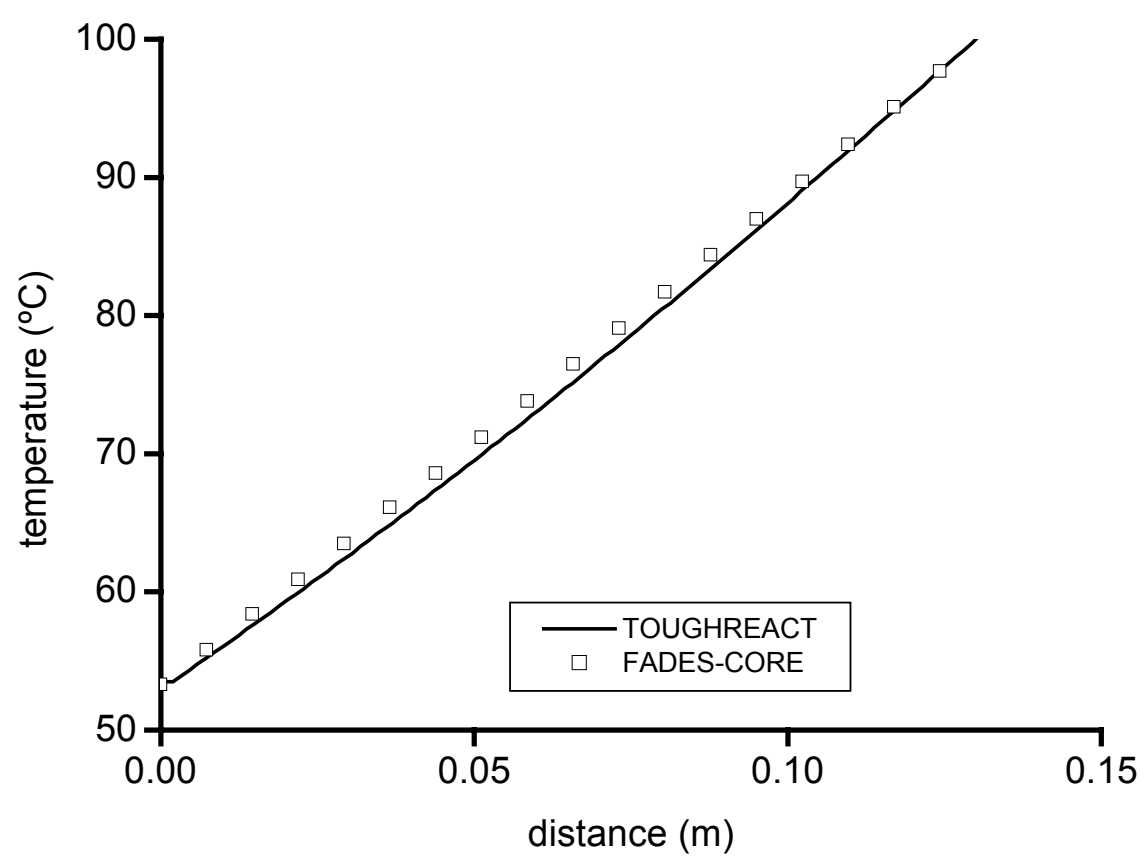

Figure 17. Comparison of temperature distributions obtained with TOUGHREACT and FADES-CORE with a steady-state heat transport. 


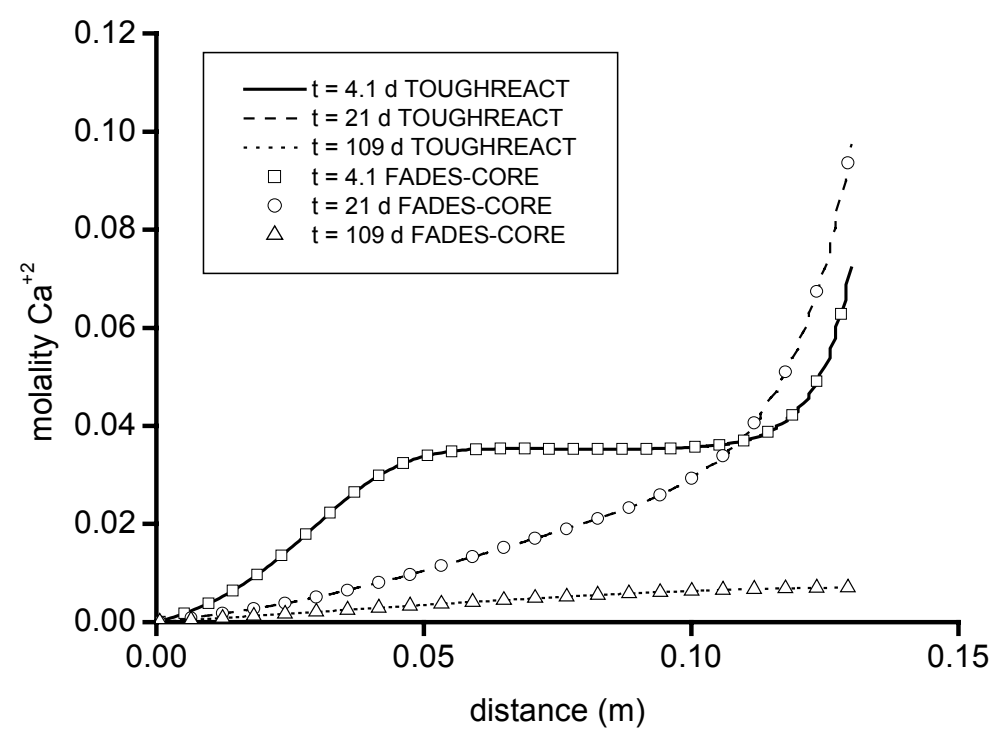

Figure 18. Comparison of $\mathrm{Ca}^{+2}$ aqueous concentration distributions at different times obtained with TOUGHREACT and FADES-CORE with a steady-state heat transport.

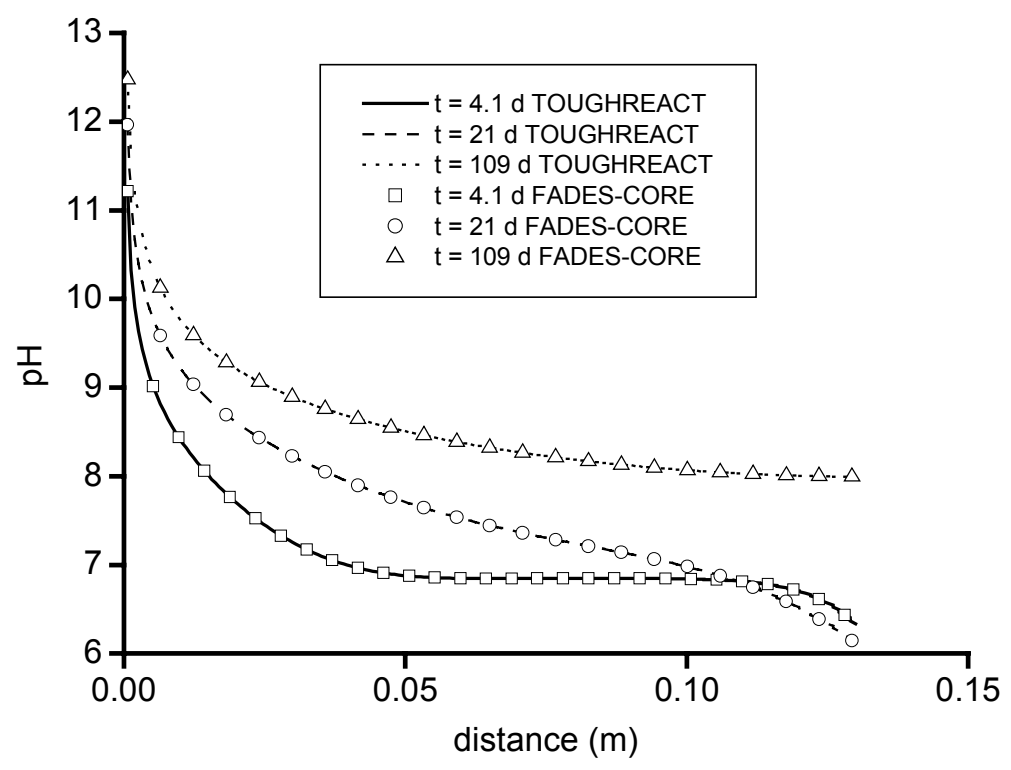

Figure 19. Comparison of $\mathrm{pH}$ concentration distributions at different times obtained with TOUGHREACT and FADES-CORE. 


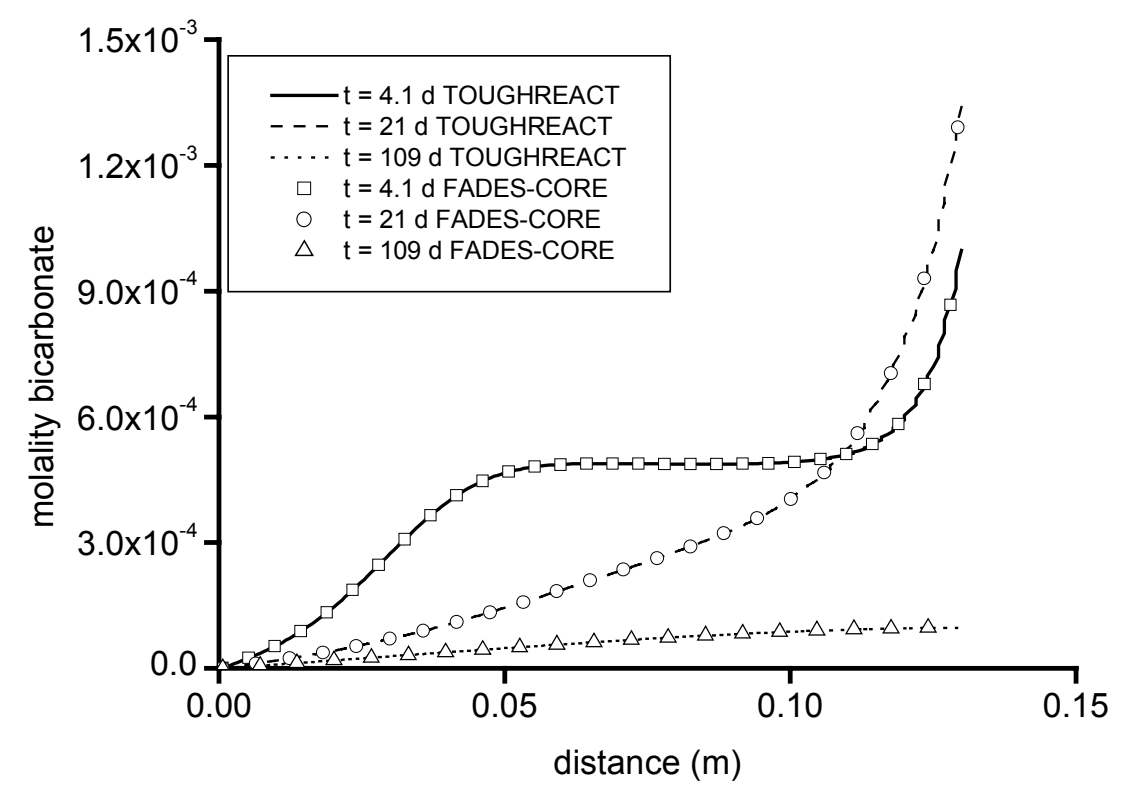

Figure 20. Comparison of bicarbonate aqueous concentration distributions obtained with TOUGHREACT and FADES-CORE at different times.

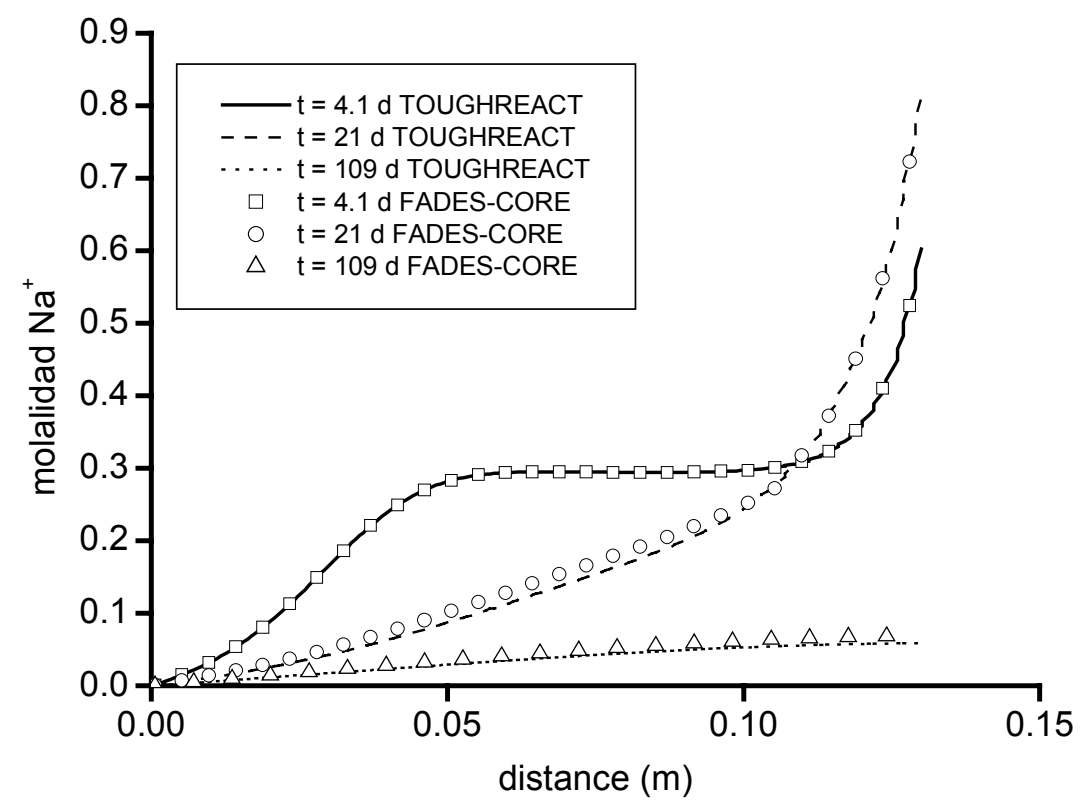

Figure 21. Comparison of $\mathrm{Na}^{+}$aqueous concentration distributions at different times obtained with TOUGHREACT and FADES-CORE. 


\section{5.- CONCLUSIONS}

The FADES-CORE code allows for the thermo-hydro-geochemical simulation of partially saturated porous media with multiphase flow. FADES-CORE has been previously verified with analytical solutions when available, otherwise with other numerical codes. The previous verification was considered as the partial verification for ensuring the correct solution of each individual component. The current verification work carried out jointly by University of La Coruña and Lawrence Berkeley National Laboratory has enhanced the verification of the FADES-CORE and TOUGHREACT codes. This effort has provided reliability of the two codes for solving real-world nonisothermal multiphase reactive transport problems.

\section{6.- ACKNOWLEDGMENTS}

This research was designed for the need to make thermo-hydro-geochemical (THG) models and codes available for the study of the behavior of porous media. Recardo Juncosa would like to thank ENRESA for the financial support for this comparative study, and also to the Xunta de Galicia, particularly to the secretaria Xeral de Investigacion e Desenvolvemento, for the co-financing they provided along with ENRESA. Recardo Juncosa is also grateful to the University of La Coruña for their assistance in performing the analysis. The contribution of Tianfu Xu and Karsten Pruess to this work was supported by the U.S. Department of Energy under Contract No. DEAC03-76SF00098. We acknowledge Keni Zhang and Huihai Liu for a review of this manuscript and the suggestion of improvements. 


\section{7.- REFERENCES}

Gershon, N. D., and A. Nir, Effect of boundary conditions of models on tracer distribution in flow through porous mediums, Water Resour. Res., 5, 830-840, 1969.

Juncosa, R., Modelos de flujo multifásico no isotermo y de transporte reactivo multicomponente en medios porosos, Tesis Doctoral. Universidad Politécnica de Madrid. 346 pp., 1999.

Lindstrom, F. T., R. Haque, V. H. Freed, and L. Boersma, Theory on the movement of some herbicides in soils: Lineal diffusion and convection of chemicals in soils, Journal of Environmental Sciencie and Technology, 1, 561-565, 1967.

Lloret, A., Comportamiento deformacional del suelo no saturado bajo condiciones drenadas y no drenadas. Tesis Doctoral. Universidad politécnica de Cataluña, 1982.

Mason, M., and W. Weaver, The settling of small particles in a fluid, Physiological Reviews, 23, 412-426, 1924.

Narasimhan, T. N., and P. A. Witherspoon, An integrated finite difference method for analyzing fluid flow in porous media, Water Resour. Res., 12, 57-64, 1976.

Navarro, V., Modelo de comportamiento mecánico e hidráulico de suelos no saturados en condiciones no isotermas. Tesis Doctoral. Universidad politécnica de Cataluña. 329 pp. 1997.

Pruess, K., TOUGH2 A general-purpose numerical simulator for multiphase fluid and heat flow. Earth Sciencies Division LWL. Berkeley, 1991.

Samper, J., R. Juncosa, J. Delgado, and L. Montenegro, CORE-LE Users Manual. Draft version. Universidad de La Coruña, 207 pp. 1998.

Villar, M. V., J. Cuevas, P. L. Martín, R. Campos, and A. M. Fernández, Model development and validation of the Thermal-Hydraulic-Mechanical and Geochemical behaviour of the clay barrier, Final report. Experimental results, Experimental results on S2 bentonite, CEC Contract F12W-CT91-0102 (DOEO), 1995.

Wolery, T. J., EQ3/6: Software package for geochemical modeling of aqueous systems: Package overview and installation guide (version 7.0), Lawrence Livermore National Laboratory Report UCRL-MA-110662 PT I, Livermore, California, 1992. 
$\mathrm{Xu}, \mathrm{T}$., Modelización del transporte no isotermo de sistemas de solutos reactivos a través de medios porosos parcialmente saturados. Tesis Doctoral. Universidad de La Coruña, 310 pp., 1996.

$\mathrm{Xu}, \mathrm{T}$., and K. Pruess, Coupled modeling of non-isothermal multi-phase flow, solute transport and reactive chemistry in porous and fractured media: 1. Model development and validation, Lawrence Berkeley National Laboratory Report LBNL-42050, Berkeley, California, 38 pp., 1998. 